\title{
CHOLESTEROL AND LIPID PEROXIDES IN ANIMAL PRODUCTS AND HEALTH IMPLICATIONS - A REVIEW*
}

\author{
Sylwia Orczewska-Dudek, Dorota Bederska-Łojewska, Marek Pieszka, \\ Mariusz P. Pietras
}

\begin{abstract}
Department of Animal Nutrition and Feed Science, National Research Institute of Animal Production, 32-083 Balice n. Kraków, Poland
\end{abstract}

\begin{abstract}
The level of oxysterols in animal products depends on the temperature used in food processing, duration of heating, and storage time and conditions. High temperature, oxygen, exposure to light, chemical composition of the product and low level of antioxidants accelerate the formation of cholesterol oxidation products (COPs). Also the high content of polyunsaturated fatty acids in meat and eggs favours the formation of oxysterols. Dairy products are characterized by the lowest content of COPs of all animal products. The most common oxysterols present in products of animal origin are 7-ketocholesterol, $20 \alpha$-hydroxycholesterol, 25-hydroxycholesterol and $\alpha$, $\beta$-epoxycholesterol. Numerous studies have confirmed the adverse effects of COPs on animal and human health. They exhibit mutagenic, carcinogenic, angiogenic and toxic action, damage cell membranes, and inhibit cholesterol biosynthesis. The use of certain antioxidants in animal nutrition limits the formation of COPs during technological processing of meat, eggs and milk, as well as during storage of fresh products. The excessive oxidation of cholesterol can be additionally prevented through the use of appropriate packaging that limits oxygen and light exposure.
\end{abstract}

Key words: cholesterol, oxidation, oxysterols, TBARS, meat, egg, milk products

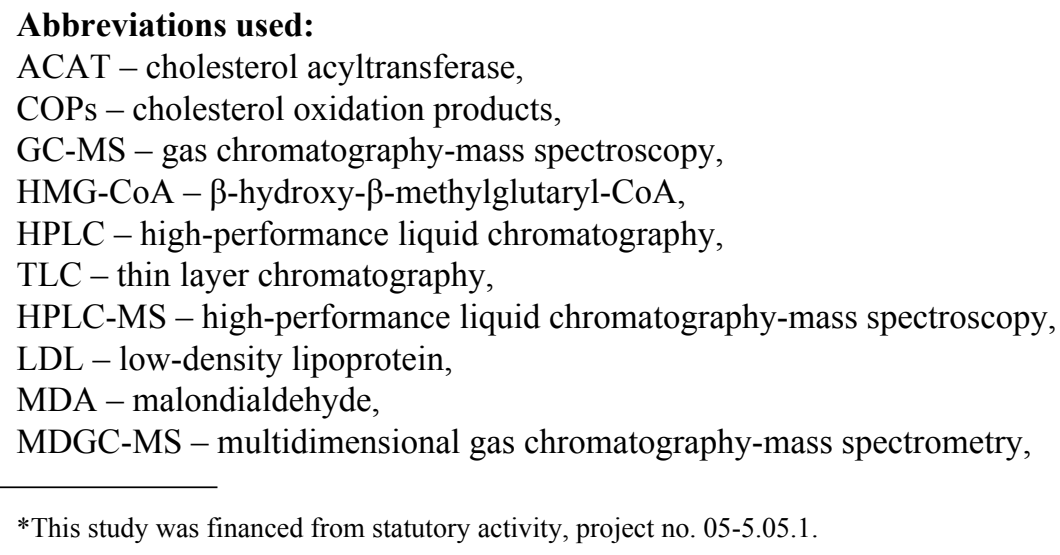


PUFA - polyunsaturated fatty acids,

TBA - thiobarbituric acid,

TBARS - thiobarbituric acid reactive substances,

TLC - thin-layer chromatography,

UHT - ultra-high temperature processing.

Owing to their high concentration of iron and sufficient levels of polyunsaturated fatty acids (PUFA) and cholesterol, meat, meat products and eggs are potentially the richest source of oxysterols, also known as cholesterol oxidation products (COPs) (Chizzolini et al., 1998; Zaborowska et al., 2002; Petrón et al., 2003). In addition, the way in which meat and meat products are stored, processed and prepared for consumption favours oxidation processes. Factors affecting these processes include the freezing method and culinary or technological treatment such as grilling, frying, boiling, smoking or lyophilizing (Paniangvait et al., 1995). To date, over 100 COPs have been identified, of which the most common in animal products are 7-hydroxycholesterol, 7-ketocholesterol, 20-hydroxycholesterol, 25-hydroxycholesterol and epimers of epoxycholesterol (Leonarduzzi et al., 2002; Hur et al., 2007; SotoRodriguez et al., 2008; Janoszka, 2010). In living cells, COPs are usually found at low concentrations. Due to their high reactivity, COPs are efficient in initiating free radical processes, which are the major factors of atherogenic and neoplastic lesions (Smith, 1996). COPs can be incorporated into cell membranes and therefore influence the membrane structure and impair their functions (Smith, 1999; Rudzińska et al., 2007). Also COPs are likely to be involved in lipid metabolism, various chronic and degenerative diseases such as cancer, aging and atherosclerosis (Schroepfer, 2000; Leonarduzzi et al., 2002; Boselli et al., 2009).

It was hypothesized that high total cholesterol content in animal food products may cause coronary heart disease. There is evidence to suggest a correlation between high blood serum cholesterol levels and the risk of cardiovascular diseases (Kumar and Singhal, 1992 a). It is now known that cholesterol is a poorly reactive molecule and atherogenic lesions in blood vessels should be ascribed mainly to the intermediate products of cholesterol oxidation, most of which are derived from cholesterol-containing foods that are processed and stored in the presence of oxygen (Schroepfer, 2000; Ryan et al., 2005).

Due to the potential health risk of consuming animal products containing COPs it is important to know more about the formation and inhibition of COPs in foods during heat treatment and storage.

The aim of this review is to evaluate the effect of cholesterol level in meat, meat products, eggs and milk products on the formation of oxysterols and their effect on human health.

\section{Structure and occurrence of cholesterol}

Cholesterol is a sterol essential to human and animal life. It is a significant component of plasma membrane and it constitutes $25-26 \%$ of the lipid molecule. Cholesterol can affect cellular functions by interacting both with different membrane lipids as well as with specific proteins (Ikonen, 2008). Cholesterol helps to generate 
a semipermeable barrier between cellular compartments and regulate membrane fluidity (Ikonen, 2008). Cholesterol modulates the function of membrane protein and participates in several membrane trafficking and transmembrane signalling processes (Ikonen, 2008). It is present at high levels in blood (average $2 \mathrm{mg} / \mathrm{mL}$ ) and in steroidogenic tissues, especially brain, where its level averages $10-20 \mathrm{mg} / \mathrm{g}$ in many species, including human (Wang and Griffiths, 2008; Griffiths and Wang, 2011). Cholesterol is the precursor of bile acids, steroid hormones and vitamin D (Simons and Ikonen, 2000; Otaegui-Arrazola et al., 2010). In the adult human, approximately $400 \mathrm{mg}$ of cholesterol per day are converted to bile acids and only approximately $50 \mathrm{mg}$ are transformed into hormones (Valenzuela et al., 2003). About a quarter of the human cholesterol is found in the central nervous system (Dietschy and Turley, 2004) and in the myelin sheath of nerve fibres (Goritz et al., 2005). It is supposed that cholesterol is important in the maturation of functional synapses (Goritz et al., 2005).

Studies of the structure, properties and potential effect of cholesterol on living organisms have been, and continue to be, one of the principal research targets in recent decades. It was not until 1932 that the structure of a cholesterol molecule was thoroughly investigated. Further discoveries have included the determination of cholesterol precursors (squalene and mevalonate) and the elucidation of regulatory mechanisms in cholesterol synthesis and transport (Vance and Bosch, 2000; Ikonen, 2008).

Cholesterol in the body is of both endogenous (synthesized in the liver) and exogenous origin (provided with food) (Valenzuela et al., 2003). Every nucleated cell can synthesize cholesterol from acetyl CoA through the mevalonate pathway. The first sterol intermediate in this pathway is lanosteol, which is further converted by several enzymes to form cholesterol (Ikonen, 2008).

\section{Cholesterol oxidation and oxysterols formation}

Cholesterol is a molecule with a double bond (Fig. 1) susceptible to oxidation. Cholesterol can be oxidized due to the activity of many molecules, including oxygen in the air, ozone, reactive singlet oxygen, hydrogen hydroperoxide, oxygen cation and hydroxide radical (Leonarduzzi et al., 2002). Because the mechanism of cholesterol oxidation is similar to that of the oxidation of fatty acids, lipid radicals formed during the processing and storage of food can accelerate the oxidation of cholesterol and generate various oxysterols (Paniangvait et al., 1995).

In the model system, Derewiaka and Obiedziński (2010 b) reported that cholesterol can be oxidized to as much as $57-68 \%$ of the initial concentration. Exogenous and endogenous cholesterol is transformed into different metabolites in human cells (Otaegui-Arrazola et al., 2010). Oxidation of cholesterol can occur in the non-enzymatic (autoxidation) and enzymatic processes (Leonarduzzi et al., 2002; Smith and Murphy, 2008). The non-enzymatic oxidation affects the sterol ring while the enzymatic process occurs in the side-chain of sterol structures (Ryan et al., 2009). However, there is a single exception: 25 -hydroxycholesterol as well as $7 \alpha$-hydroxycholesterol can be produced by both enzymatic and non-enzymatic processes (Gill et al., 2008; Otaegui-Arrazola et al., 2010). 


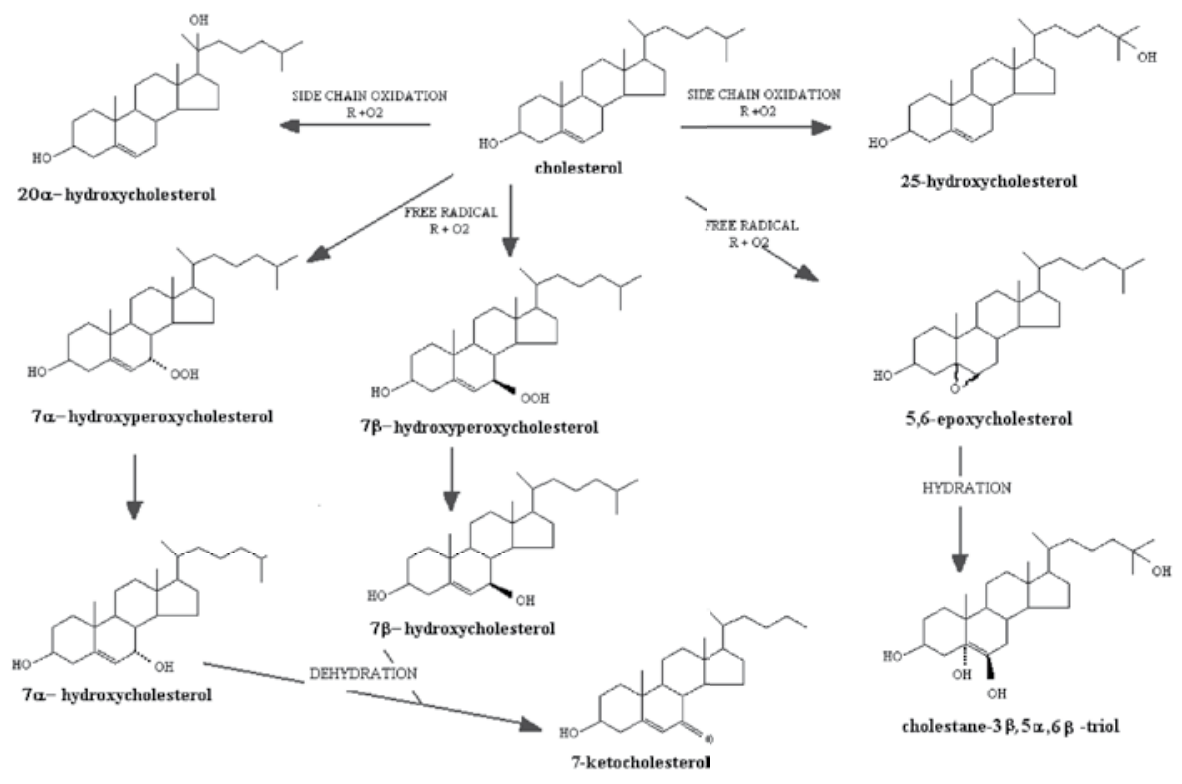

Figure 1. Oxidation pathways of cholesterol (cholest-5-en-3 $\beta$-ol)

The enzymatic oxidation of sterols involves groups of enzymes, mainly hydroxylases, which contribute to the formation of various COPs. The main groups of enzymes are monooxygenases, dehydrogenases and diooxygenases (Smith, 1996; Leonarduzzi et al., 2002; Derewiaka and Obiedziński, 2010 b). These enzymes are responsible for the production of stenodiol derivatives, sterol epoxides, sterol ketones, and sterol peroxides (Smith,1996). Also there are several enzymes like epoxydase which may reduce hydroperoxides to epoxycholesterols. These epoxysterols can be converted into their triol end products (Tai et al., 1999). Enzymatic side-chain hydroxylation of cholesterol can generate 24-, 25- and 27-hydroxycholesterols as well as $7 \alpha$-hydroxycholesterol (Russell, 2000; Rozner and Garti, 2006). The 25-hydroxycholesterol regulates the sterol regulatory element binding protein for the cholesterol-dependent transcriptional regulation (Russell, 2000; Iguchi et al., 2010). Overexpression of cholesterol 25-hydroxylase in a cell line increased the generation of 25-hydrocholesterol, and suppressed sterol regulatory element-binding protein processing and cholesterol synthesis (Lund et al., 1998). Oxysterols have been shown to be biologically active molecules as ligands to nuclear receptors (Iguchi et al., 2010) and to have effect on the immune system including suppressing the production of IgA by B cells (Bauman et al., 2009; Griffiths and Wang, 2011). The enzymatic oxidation of cholesterol in a variety of tissues yields more oxysterol products for which key physiological roles are recognized (Russell, 2000). 
Cholesterol autoxidation (non-enzymatic oxidation) has been studied for many decades, although systematic research did not begin until 1960. This research gained momentum following reports indicating that COPs and oxysterols are detrimental to human health.

Autoxidation is a very extensive process resulting in a complex mixture of COPs. It is a radical process involving the same reactions as the autoxidation of unsaturated fatty acids. Table 1 gives a list of the most common oxysterols in products of animal origin.

Cholesterol autoxidation has been studied in detail and is well documented (Smith, 1996). When cholesterol is in a crystalline state and in the presence of air, the oxidation reaction is governed by the arrangement of molecules in the crystal. Cholesterol molecules are organized into double layers with 3-hydroxyl groups and with side chains exposed to chemical reactions (Smith, 1996).

The function of cholesterol molecules as an integral part of the double cell membrane layer is closely associated with the properties of membrane phospholipids (Ikonen, 2008). Because cholesterol contains one $\Delta^{\prime}$-double bond, it is expected that cholesterol oxidation will be initiated by the formation of free radical (Smith, 1996). Smith (1996) suggests that the hydroxyperoxidation of PUFA that takes place during lipid oxidation may be necessary for initiating the cholesterol oxidation process. The high level of PUFA in membrane phospholipids and the fact that they are vulnerable to the attacks of oxidizing compounds within cells and in the proximity of cell membranes makes the initiation of lipid oxidation at intracellular membrane level possible (Igene and Pearson, 1979; Hur et al., 2007).

Smith (1996) postulated that cholesterol oxidation in food and biological systems can occur intramolecularly and intermolecularly. In the intramolecular system, hydrogen is extracted from cholesterol by the peroxy or oxy radicals of an adjacent oxidized PUFA or cell membrane phospholipid. In the intermolecular system, the oxidized acyl portion attacks cholesteryl portions of the same cholesteryl ester molecule. Both mechanisms could operate within muscle cell membrane.

It is assumed that the autoxidation reactions are initiated by the formation of a peroxy radical situated by the carbon in the position at the $\mathrm{C} 7$ of the sterol ring. The radical may generate a reaction with oxygen which results in formation of a cholesterol peroxyl radical, which further reacts abstracting hydrogen and generates relatively stable cholesterol 7-hydroperoxides, the primary oxidation product (Brown and Jessup, 2009; Busch and King, 2009) created during heating (Tai et al., 1999). Cholesterol hydroperoxides in the presence of sterol hyperoxide or triglycerides may be subject to epoxydation process in the result of which epoxycholesterols are created or cholesterol hydroperoxides can be converted into cholesterol-diols and ketocholesterols (Busch and King, 2009; Otaegui-Arrazola et al., 2009). These secondary products can be further altered by epimerizations and dehydrations (Busch and King, 2009). The non-enzymatic oxidation (autoxidation) generates $7 \alpha$, $\beta$-hydroxycholesterols and 7-ketocholesterol and cholesterol-5ß, 6ß-epoxide (Brown and Jessup, 2009; Busch and King, 2009), which are widespread in foods (Tai et al., 1999; Lercker et al., 2002). 
The oxysterols contained in cholesterol-rich food (meat and meat products, eggs, dairy products) are most probably generated in a non-enzymatic way during cooking, processing and storage (Brown and Jessup, 2009). Some studies reported the effect of heat treatment on the formation of cholesterol oxides and showed that temperature and time are determinant factors in this process, directly influencing the rate of oxidation and affecting the type and the amounts of products formed (Echarte et al., 2001; Rudzińska et al., 2009; Derewiaka and Obiedziński, 2010 a). Derewiaka and Obiedziński (2010 b) have demonstrated that the heating of pork lard in higher temperatures for longer time leads to the enhanced formation of COPs. They also showed the relation between thickness of the lard layers and the content of COPs. The concentration of COPs in thin and thick lard layer after heating for 60 minutes amounted to 10.1 and $6.3 \mu \mathrm{g} / \mathrm{g}$, respectively. The presented research indicates that deep frying may reduce the intake of COPs in human diet (Derewiaka and Obiedziński, 2010 b), which is desirable from the standpoint of human health.

Table 1. Systematic and trivial names of the most common oxysterols in animal products (Paniangvait et al., 1995)

\begin{tabular}{|c|c|c|}
\hline Trivial name & Systematic name & Abbreviation \\
\hline Cholesterol & cholest-5-en-3 $\beta$-ol & $-\mathrm{C}$ \\
\hline $7 \alpha$-hydroxycholesterol & cholest-5-en-3 $\beta, 7 \alpha$-diol & $7 \alpha-\mathrm{OH}-\mathrm{C}$ \\
\hline $7 \beta$-hydroxycholesterol & cholest-5-en-3 $\beta, 7 \beta$-diol & $7 \beta-\mathrm{OH}-\mathrm{C}$ \\
\hline 7-ketocholesterol & $3 \beta$-hydroxycholest-5-en-7-one & 7-keto-C \\
\hline$\alpha$-epoxycholesterol & $5 \alpha, 6 \alpha$-epoxy-5-cholestan-3 $\beta$-ol & cholesterol- $5 \alpha, 6 \alpha$-epoxy-C/ $\alpha$-ep \\
\hline$\beta$-epoxycholesterol & $5 \beta, 6 \beta$-epoxy-5-cholestan-3 $\beta$-ol & cholesterol- $5 \beta, 6 \beta$-epoxy-C/ $\beta$-ep \\
\hline 19-hydroxycholesterol & cholest-5-en-3 $\beta, 19$-diol & 19-OH-C \\
\hline 25-hydroxycholesterol & cholest-5-en-3 $\beta, 25$-diol & $25-\mathrm{OH}-\mathrm{C}$ \\
\hline Cholestanetriol & $5 \alpha$-cholestane- $3 \beta, 5,6 \beta$-triol & $3 \beta, 5 \alpha, 6 \beta$-trihydroxycholesterol/triol \\
\hline
\end{tabular}

\section{Effect of oxysterols on cholesterol metabolism}

Most of the cholesterol in the human body is synthesized (approximately $1 \mathrm{~g}$ per day), with only $0.3 \mathrm{~g}$ per day ingested in the diet. It is suggested that high cholesterol intake, i.e. 0.6-0.8 g per day can cause hypercholesterolemia and increase the risk of atherosclerosis development (Ziemlański and Budzyńska-Topolewska, 1991). The tissues capable of cholesterol synthesis are the liver, adrenal cortex, skin, intestines, testes and aorta (Valenzuela et al., 2003). Cholesterol synthesis takes place in the microsomal and cytosolic fraction of the cell. COPs have strong properties weakening cholesterol synthesis in many tissues. Indirectly, this activity is associated mainly with inhibition of $\beta$-hydroxy- $\beta$-methylglutaryl-CoA (HMG-CoA - EC 1.1.1.34), a key enzyme regulating cholesterol synthesis. It has been shown that COPs degrade this enzyme and thus reduce cholesterol synthesis (Chizzolini et al., 1998). As a result of inhibition of HMG-CoA reductase in the cell membrane, cholesterol content is decreased, which in turn negatively affects the cell membrane functions. This is paralleled by a reduction in DNA synthesis, thus contributing to reduced accumulation of cell proteins (Schroepfer, 2000). 
Cholesterol esterification and the activity of the enzyme acyl-CoA: cholesterol acyltransferase (ACAT - EC 2.3.1.26) in the liver, fibroblasts, and the cells of smooth muscles and other tissues are increased by 25-hydroxycholesterol (25-OH-C) (Russell, 2000).

ACAT stimulation coupled with the inhibition of HMG-CoA reductase and other enzymes involved in cholesterol biosynthesis suggests that oxysterols may regulate the cellular metabolism of cholesterol (Russell, 2000; Rudel et al., 2001). A similar inhibitory effect on the synthesis and metabolism of cholesterol may be exerted by phytosterols (plant sterols such as campesterol, sitosterol and stigmasterol) (Kozłowska-Wojciechowska et al., 2003). These compounds - similar in chemical structure to cholesterol and commonly found in vegetable oils - are subject to the same oxidation processes, thus producing oxygen derivatives (Dutta, 1997; Rudzińska et al., 2001), volatile flavour components and oligomers (Rudzińska et al., 2009).

\section{Methods used for the determination of COPs in products of animal origin}

The analysis of COPs has been difficult because of their low concentrations in foods (Tai et al., 1999). Methods for COPs analysis have been developed for decades. At present, the level of cholesterol derivatives and lipids in food products is generally evaluated using chromatography techniques, including thin-layer chromatography (TLC), gas chromatography (GC) and high-performance liquid chromatography (HPLC) (Ryan et al., 1981; Chen et al., 1994; Przygoński et al., 2000). The most useful techniques are GC-MS (gas chromatography-mass spectroscopy), MDGC-MS (multidimensional gas chromatography-mass spectrometry) and HPLCMS (high pressure liquid chromatography-mass spectroscopy), which give a thorough and reliable quantitative and qualitative analysis of oxysterols (Petrón et al., 2003; Karu et al., 2007).

\section{Oxysterols in products of animal origin}

Animal food products such as milk products, eggs and egg products, and meat and meat products are the principal source of cholesterol in our diet (Leonarduzzi et al., 2002). Overall results from several sources showed that fresh food contained none or undetectable levels of COPs. Most of the oxysterols were identified in foods subjected to various treatments such as heating at high temperature, prolonged storage, irradiation during storage, etc. (Hur et al., 2007). These treatments may induce cholesterol oxidation (Pie et al., 1991; Paniangvait et al., 1995). Therefore, the COPs and cholesterol content of these products should be accounted for in the nutritional evaluation of food products (Table 2). Parallel to the identification of COPs which can be dangerous for health and of their action at the cellular level, it is necessary to make an effort to prevent oxysterol formation during the different stages of food processing and storage conditions. 
Table 2. Fat and cholesterol content of animal products

\begin{tabular}{|c|c|c|c|}
\hline Products & $\begin{array}{c}\text { Fat } \\
(\mathrm{g} / 100 \mathrm{~g})\end{array}$ & $\begin{array}{c}\text { Cholesterol } \\
\text { (mg/100 g of products) }\end{array}$ & References \\
\hline Meat and meat products & & & Chizzolini et al., 1998 \\
\hline Beef & 1.90 & 60 & \\
\hline Pork & 1.86 & 65 & \\
\hline Mutton, fillets & 3.41 & 70 & \\
\hline Poultry meat, average & 5.60 & 81 & \\
\hline Turkey meat, average & 15.00 & 74 & \\
\hline Hamburgers & 13.01 & 44 & \\
\hline Pork frankfurters & 24.40 & 65 & \\
\hline Beef frankfurters & 25.50 & 40 & \\
\hline Poultry frankfurters & 23.40 & 94 & \\
\hline Salami (Milano) & 31.00 & 71 & \\
\hline Mortadella & 27.00 & 81 & \\
\hline Ham (Parma) & 16.00 & 80 & \\
\hline Dairy products & Fat $(\%)$ & $\begin{array}{c}\text { Cholesterol } \\
\text { (mg/100 g of products) }\end{array}$ & Piironen et al., 2002 \\
\hline Milk & 3.50 & 11.2 & \\
\hline Milk & 1.50 & $5.6-6.4$ & \\
\hline Cream & 10.00 & 27.5 & \\
\hline Cream & 38.00 & 76.9 & \\
\hline Milk powder & 1.00 & 16.5 & \\
\hline Cheese & $11.00-30.00$ & $33.2-82$ & \\
\hline Egg, whole & $9.30-9.70$ & $361-370$ & \\
\hline
\end{tabular}

\section{Level of oxysterols in meat and meat products}

The most common oxysterols in meat products are $7 \beta$-hydroxycholesterol, 5,6 $\alpha$ epoxycholesterol, 5,6ß-epoxycholesterol, 7-ketocholesterol and 25-hydroxycholesterol (Hur et al., 2007; Soto-Rodriquez et al., 2008; Derewiaka and Obiedziński, 2010 a). Fresh meat usually contains only trace amounts of oxysterols (Park and Adis, 1985; Eder et al., 2005), but meat subjected to culinary treatment contains significant amounts of COPs and is usually the main source of oxysterols in our diets (Hur et al., 2007). A particularly large amount of COPs is generated in products subjected to preliminary thermal treatment and then stored in a refrigerator (Vicente and Torres, 2007). Under these conditions, the level of COPs may increase several-fold (Table 3) (Ahn et al., 2001). During storage of turkey meat, pork and beef in a refrigerator and exposure to oxygen, the largest amount of cholesterol oxides is formed in turkey meat and the smallest in beef (Nam et al., 2001) (Table 4). Park and Addis (1985) reported that cholesterol in raw meat is not easily oxidized. However, when meat samples were freeze-dried (lyophilized) or dried using the spray method, these conditions favoured dehydration and thus increased cholesterol oxidation.

This means that dehydrated products are more reactive. The sun or oven-dried beef (typical Mexico product called machaca) for approximately $8 \mathrm{~h}$ at $68-95^{\circ} \mathrm{C}$ contained a lot of COPs (Soto-Rodriguez et al., 2008). The content of 7-ketocholesterol 
was higher than the other COPs found in the machaca, because the starting oxidized product 7-hydroperoxycholesterol and 7-hydroxycholesterol, were transformed into the more stable 7-ketocholesterol by dehydration or dehydrogenation, respectively (Smith, 1996; Soto-Rodriguez et al., 2008). An important role in the formation of various COPs is played by temperature of technological process. Fresh bovine brain, liver and muscles contained none of the analysed oxysterols, while dehydrated food in tablet form contained from $13.8 \mu \mathrm{g} / \mathrm{g}$ of 7 -ketocholesterol to $46.1 \mu \mathrm{g} / \mathrm{g}$ of $7 \alpha$-hydroxycholesterol (Paniangvait et al., 1995). Many studies indicate that the amount of COPs in food may often reach from $1 \%$ to $10 \%$ of total cholesterol or even more (Kumar and Singhal, 1992 b; Hur et al., 2007; Derewiaka and Obiedziński, 2009). The results of many experiments have indicated that the physical status of cholesterol has a fundamental effect on the types of product oxidation.

Table 3. Concentration of cholesterol oxidation products $(\mathrm{mg} / \mathrm{kg})$ in preboiled turkey, beef and pork meat $\left(85^{\circ} \mathrm{C}\right.$ for $\left.25 \mathrm{~min}\right)$ stored for 7 days in vacuum packages or in the presence of oxygen (Ahn et al., 2001)

\begin{tabular}{l|c|c|c|c}
\hline \multirow{2}{*}{\multicolumn{1}{c}{ Item }} & \multicolumn{2}{|c|}{ Day 0 } & \multicolumn{2}{c}{ After 7 days of storage at $4^{\circ} \mathrm{C}$} \\
\cline { 2 - 5 } & $\begin{array}{l}\text { vacuum } \\
\text { package }\end{array}$ & $\begin{array}{c}\text { package with } \\
\text { oxygen exposure }\end{array}$ & $\begin{array}{c}\text { vacuum } \\
\text { package }\end{array}$ & $\begin{array}{c}\text { package with } \\
\text { oxygen exposure }\end{array}$ \\
\hline $\begin{array}{l}\text { Turkey meat - legs } \\
\text { TBARS, mg MDA/kg }\end{array}$ & 3.95 & 4.55 & 4.44 & 10.87 \\
$\begin{array}{l}\text { Sum of cholesterol oxides } \\
\text { Pork tenderloin }\end{array}$ & 74.4 & 53.8 & $160.1 \mathrm{~b}$ & $568.1 \mathrm{a}$ \\
$\begin{array}{l}\text { Sum of cholesterol oxides } \\
\text { Beef sirloin }\end{array}$ & 61.9 & & & \\
Sum of cholesterol oxides & 29.9 & 63.2 & & $170.4 \mathrm{a}$ \\
\hline
\end{tabular}
$\mathrm{a}, \mathrm{b}, \mathrm{c}-\mathrm{P} \leq 0.05$.

Table 4. Level of cholesterol oxides ( $\mu \mathrm{g} / \mathrm{g}$ fat) in minced meat stored for 7 days in a refrigerator $\left(4^{\circ} \mathrm{C}\right)$ in the presence of oxygen (Nam et al., 2001)

\begin{tabular}{lcccc}
\hline \multicolumn{1}{c}{ Cholesterol oxides } & Turkey meat (leg) & Pork tenderloin & Beef sirloin \\
\hline $7 \alpha$ - and 7 $\beta$-hydroxycholesterol & 51.9 & 29.2 & 11.8 \\
$5,6 \alpha$-epoxycholesterol & 6.4 & 7.6 & 16.1 \\
$5,6 \beta$-epoxycholesterol & nd & nd & 3.7 \\
$20 \alpha$-hydroxycholesterol & nd & nd & 5.3 \\
cholestantriol & nd & 1.1 & 0.3 \\
7-ketocholesterol & 19.0 & 15.0 & 8.4 \\
\hline
\end{tabular}

nd - not detectable.

Osada et al. (1993) reported the occurrence of COPs in traditionally processed seafood that is intensively consumed in Japan. The total level of COPs ranged from $8.3 \mu \mathrm{g} / \mathrm{g}$ in boiled and dried shrimp to $188 \mu \mathrm{g} / \mathrm{g}$ in boiled and dried anchovies. Of all 
the food products analysed, anchovies contain the highest level of COPs. Also Mexico is an important producer and consumer of sun-dried shrimps which contain a high amount of COPs, especially 7-ketocholesterol (Soto-Rodriguez et al., 2008). SotoRodriguez et al. (2008) suggested that the technology process such as salting, direct light-exposure and large surface contact with air for relatively long time periods used for the production of sun-dried shrimp can induce cholesterol oxidation. Echarte et al. (2001), who investigated the oxidation of lipids and cholesterol in salmon samples roasted or fried in olive oil or soybean oil, found the highest increase in the level of oxysterols, mainly $7 \beta$-hydroxycholesterol and 7-ketocholesterol in salmon samples roasted without oil. Derewiaka and Obiedziński (2010 a) showed that in the fish fillets and minced meat (beef and pork) fried in rapeseed oil, the most abundant COP was 7-ketocholesterol. Significantly higher levels of COPs were found in fried beef minced meat $(828.8 \mu \mathrm{g} / 100 \mathrm{~g})$ than in pork minced meat $(565.5 \mu \mathrm{g} / 100 \mathrm{~g})$. In the same experiment, the authors identified a high content of triol $(82.4 \mu \mathrm{g} / 100 \mathrm{~g})$ in cordon-blue chops after frying, which was not present before thermal processing. The highest cholesterol content was observed in raw minced meat, but during frying its content decreased due to thermal degradation and oxidation (Derewiaka and Obiedziński, 2010 a). Janoszka (2010) reported the highest level of 7-ketocholesterol and 7-hydroxycholesterol in grilled minced chops. The formation of a high amount of these oxysterols probably was caused by the large surface exposure of the minced meat to air. In the meat of Iberian pigs cooked using different methods like grilling, frying in olive oil, microwaving and roasting, the highest level of 7-hydroxycholesterol was observed $(151.1,137.1,155,159.8 \mu \mathrm{g} / 100 \mathrm{~g}$ of muscle, respectively). The 7-ketocholesterol was present in trace quantities (Broncano et al., 2009). The content of COPs in thermally processed meat and meat products was significantly higher than in raw animal foodstuff (Broncano et al., 2009), which was caused by cholesterol autoxidation (Derewiaka and Obiedziński, 2010 a). In addition, the level of oxysterol in commercial pâtés containing pork liver and in dry fermented sausages was $12.6-18.6$ and $46.9-113.5 \mu \mathrm{g} / 100 \mathrm{~g}$ of products, respectively (Derewiaka and Obiedziński, 2010 a). Table 5 presents the findings of Zaborowska et al. (2002), who analysed the composition of some cured meats for the level of total cholesterol, fat and total cholesterol oxides. The highest cholesterol and COPs levels were characteristic of cured meats that were dried and richer in cholesterol and fat. In the same study, the authors discussed some interesting correlations between the level of fat in cured meats and the concentration of individual oxysterols (Table 6).

The consumer is not always aware that the mean lipid content of pork loin is $10 \%$ of the basic wet weight, of which triglycerides and phospholipids are the main components and cholesterol is less abundant, as it ranges from 55 to $65 \mathrm{mg} / 100 \mathrm{~g}$ of meat tissue (Maraschiello et al., 1995). Recent studies have focused on the effect of different dietary fat supplements on the formation of oxidized forms of cholesterol. The study of Pieszka (2007 a) investigated the effect of different vegetable oils (palm, sunflower, rape and linseed oils) in fattening pig diets on the cholesterol and oxysterol content and oxidative stability of the $m$. longissimus. In the meat of pigs receiving a dietary supplement of PUFA-rich linseed and sunflower oils, the oxidation processes were amplified, especially after long periods of frozen storage 
of meat (6 months). A significantly higher lipid oxidation level (TBARS) and level of oxysterols was found. The lowest level of oxysterols in the m. longissimus was found in pigs receiving palm oil (Table 7).

Table 5. Levels of fat (\%), cholesterol and sum of cholesterol oxidation products ( $\mu \mathrm{g} / \mathrm{g}$ of sample) in the Polish sausages analysed (Zaborowska et al., 2002)

\begin{tabular}{lcccc}
\hline \multicolumn{1}{c}{ Type of sausages } & Fat & Cholesterol & Sum of COPs \\
\hline Piwna & 20.7 & 673.6 & 11.8 \\
Wiejska & 23.7 & 687.2 & 12.4 \\
Jałowcowa & 38.6 & 821.5 & 11.65 \\
Śląska & 19.3 & 271.8 & 22.02 \\
Kabanos & 22.8 & 425.8 & 25.6 \\
Polska 1 & 19.0 & 484.7 & 9.79 \\
Polska 2 & 20.6 & 549.2 & 8.40 \\
Polska 3 & 17.5 & 613.6 & 9.78 \\
Salami & 34.8 & 244.4 & 25.44 \\
Pasztetowa 1 & 36.4 & 847.8 & 22.61 \\
Pasztetowa 2 & 32.6 & 253.0 & 25.83 \\
Mortadela & 21.2 & 346.7 & 8.04 \\
Metka łososiowa & 51.5 & 353.1 & 36.52 \\
Parówkowa & 27.3 & 366.0 & 4.42 \\
Mielonka & 12.8 & 367.5 & 11.60 \\
Metka wędzona & 57.6 & 829.7 & 23.71 \\
\hline
\end{tabular}

Table 6. Determination of coefficients $\left(\mathrm{r}^{2}\right)$ between fat content and oxysterols, cholesterol and total sum of oxysterols in Polish commercial sausages (Zaborowska et al., 2002)

\begin{tabular}{l|l}
\hline \multicolumn{1}{c|}{ Discriminant } & Fat \\
\hline$\beta$ epoxy-C & $0.453^{*}$ \\
$20 \alpha-O H C$ & 0.012 \\
$27-O H C$ & 0.001 \\
$7 \alpha-O H C$ & 0.031 \\
7 keto-C & 0.059 \\
$\alpha$ epoxy-C & 0.081 \\
$25-O H C$ & 0.180 \\
7 -OHC & $0.289^{*}$ \\
Triol-C & $0.327^{*}$ \\
Sum of oxysterols & $0.394^{*}$ \\
Cholesterol & 0.085 \\
\hline
\end{tabular}

*Statistically significant results at $\mathrm{P} \leq 0.05$. 
Table 7. Effect of type of oil supplement in pig diets on the level of vitamin E, TBARS, total cholesterol and sum of oxysterols in $m$. longissimus dorsi after storage of meat at $-19^{\circ} \mathrm{C}$

(Pieszka, 2007 a)

\begin{tabular}{l|c|c|c|c|c}
\hline \multirow{2}{*}{\multicolumn{1}{c|}{ Item }} & \multicolumn{4}{c|}{} & \multirow{2}{*}{ SE } \\
\cline { 2 - 5 } & $\begin{array}{c}\text { palm } \\
\text { oil }\end{array}$ & $\begin{array}{c}\text { linseed } \\
\text { oil }\end{array}$ & $\begin{array}{c}\text { rapeseed } \\
\text { oil }\end{array}$ & $\begin{array}{c}\text { sunflower } \\
\text { oil }\end{array}$ & \\
\hline TBARS after 90 days $\left(\mathrm{mg} / \mathrm{kg}^{-1}\right)$ & 0.509 & 0.526 & 0.568 & 0.499 & 0.01 \\
TBARS after 180 days $\left(\mathrm{mg} / \mathrm{kg}^{-1}\right)$ & $0.756 \mathrm{~A}$ & $1.004 \mathrm{~B}$ & $0.976 \mathrm{~B}$ & $0.895 \mathrm{AB}$ & 0.02 \\
$\alpha$-tocopherol $(\mu \mathrm{g} / \mathrm{g})$ & $2.48 \mathrm{~B}$ & $1.72 \mathrm{~A}$ & $2.08 \mathrm{AB}$ & $1.91 \mathrm{AB}$ & 0.08 \\
Total cholesterol $\left(\mathrm{mg} / \mathrm{kg}^{-1}\right)$ & 65.19 & 64.17 & 62.64 & 65.11 & 0.94 \\
Sum of oxysterols $(\mu \mathrm{g} / \mathrm{g})$ & $22.1 \mathrm{~A}$ & $28.6 \mathrm{~B}$ & $23.8 \mathrm{~A}$ & $26.8 \mathrm{~B}$ & 0.11 \\
\hline
\end{tabular}

$\mathrm{A}, \mathrm{B}-\mathrm{P} \leq 0.01$.

It is believed that feeding additives such as type of fat (oil) and antioxidant vitamins ( $\mathrm{C}, \mathrm{E}$ and others) limit the formation of oxidized form of cholesterol and improve the dietetic and health value of meat. In the study of Pieszka (2007 b) vitamin E, supplemented to complete diets at amounts of $200 \mathrm{mg} / \mathrm{kg}$ caused a significant increase in the vitamin $E$ content of meat $(P \leq 0.01)$. A highly significant relationship was found between the dietary supply of vitamins and the sex of animals $(P=0.001)$. The vitamin supplements used did not have a significant effect on the level of total cholesterol in meat. Supplementation of $\beta$-carotene and vitamins $E$ and $C$ had a significant effect on limiting the formation of oxygenated cholesterol derivatives. This effect was most noticeable with the combined use of vitamins ( $\beta$-carotene, vitamins $\mathrm{E}$ and $\mathrm{C})$ and in the groups receiving vitamin $\mathrm{C}$ and vitamin $\mathrm{E}$ alone $(\mathrm{P} \leq 0.01)$. Six oxysterols were identified, with 7-ketocholesterol accounting for $66 \%$ of all oxysterols.

Eder et al. (2005) investigated the effect of fatty acid-enriched diets and vitamin E supplementation on the level of oxysterols in pork and cured meats. A significant relationship was found between oxysterol content according to the type of fat supplement and the dietary level of vitamin $\mathrm{E}$. The meat of fatteners receiving higher vitamin E rations and palm oil was characterized by lower TBARS and lower oxysterol levels in meat and meat products. Meanwhile, poultry carcass cholesterol content was reduced by adding higher vitamin $\mathrm{E}$ doses to chicken diets.

Galvin et al. (1998) fed broilers with a standard diet supplemented with 20, 200 or $800 \mathrm{mg}$ of tocopheryl acetate $/ \mathrm{kg}$ feed. The increasing amounts of vitamin $\mathrm{E}$ in the feed increased the $\alpha$-tocopherol concentration in carcass, including when the carcasses were stored in a refrigerator and later boiled (Table 8). Rey et al. (2001) gave fattening pigs diets containing vegetable oils (sunflower oil, olive oil and flaxseed) and supplemented with $\alpha$-tocopheryl acetate (10 or $200 \mathrm{mg} / \mathrm{kg}$ feed). Higher supplements of vitamin E significantly reduced the COPs content of boiled meat. A similar reduction in cholesterol oxidation in veal was obtained by Engeseth et al. (1993), who fed animals a ration enriched with vitamin $\mathrm{E}$.

Turkey meat and pork contained the highest levels of $7 \alpha$-hydroxycholesterol, $7 \beta$ hydroxycholesterol and 7-ketocholesterol, whereas beef was richest in epoxide de-

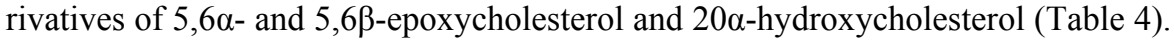


There is greater COPs formation in meat with a higher PUFA content. This process can be inhibited by supplementing sodium nitrite or plant antioxidants such as apple catechins (Osada et al., 2000). Lopez-Bote et al. (1998) supplemented broiler diets with rosemary or sage oil and tocopheryl acetate. In the meat of birds receiving spice oils, the concentration of cholesterol oxides was lower than in the meat samples from control birds. The greatest effect on reducing COPs concentration was exerted by supplemental vitamin E. The use of protein hydrolysates in processing as shown by Flaczyk et al. (2006) and Rudzińska et al. (2007) appears to be an efficient way to reduce the formation of oxysterols in meat products.

Table 8. Effect of vitamin E level in broiler feeds on $\alpha$-tocopherol concentration and $20 \alpha$-hydroxycholesterol in thawed and ground breast muscles of birds. Ground samples were stored for 12 days in a refrigerator at $4^{\circ} \mathrm{C}$ (Galvin et al., 1998)

\begin{tabular}{|c|c|c|c|}
\hline $\begin{array}{l}\alpha \text {-tocopheryl acetate } \\
\text { per mg/kg feed }\end{array}$ & $\begin{array}{c}\alpha \text {-tocopherol, } \mathrm{mg} / \mathrm{kg} \\
\text { of freshly ground } \\
\text { samples }\end{array}$ & TBARS, mg MDA/kg & $20 \alpha$-hydroxycholesterol \\
\hline 20 & $4.8 \mathrm{a}$ & $4.3 \mathrm{c}$ & $1.4 \mathrm{c}$ \\
\hline 200 & $19.8 \mathrm{~b}$ & $1.8 \mathrm{~b}$ & $0.6 \mathrm{~b}$ \\
\hline 800 & $47.9 \mathrm{c}$ & $0.9 \mathrm{a}$ & $0.3 \mathrm{a}$ \\
\hline
\end{tabular}

$\mathrm{a}, \mathrm{b}, \mathrm{c}-\mathrm{P} \leq 0.05$.

In other studies, Maraschiello et al. (1998) used $\beta$-carotene or vitamin E supplements in complete diets for broiler chickens to inhibit lipid and cholesterol oxidation processes. The increased dose of vitamin $\mathrm{E}$ in the diet $(200 \mathrm{mg} / \mathrm{kg}$ feed $)$ significantly limited the level of oxysterols in boiled meat. The $\beta$-carotene supplement used (15 or $45 \mathrm{mg} / \mathrm{kg}$ feed) exhibited no antioxidative effect. The use of natural antioxidants in the food industry, to limit COPs formation in meat products, among other things, is still limited.

It has long been known that several per cent of cholesterol and fatty acids is oxidized in deep-frying fat. In polyunsaturated fats (soybean, linseed, sunflower and sardine oils and triolein), cholesterol was oxidized more rapidly than in saturated fat (tristearin and beef fat). When cholesterol was heated with unsaturated fat, especially sardine oil, it decomposed after only 1 hour. 7-ketocholesterol, similar to $5 \beta$-epoxycholesterol and $5 \alpha$-epoxycholesterol, proved to be the most susceptible to oxidation. Trace amounts of $7 \alpha$-hydroxycholesterol and $7 \beta$-hydroxycholesterol were found. These results reflect the instability of saturated fatty acids during oxidation at high temperature (Osada et al., 1993). The effect of deep frying in sunflower oil at a temperature of $160^{\circ}$ to $180^{\circ} \mathrm{C}$ on the formation of cholesterol oxides was investigated by Echarte et al. (2001). Fresh loin was found to contain less than $1 \mathrm{mg}$ COPs $/ \mathrm{kg}$ and $9-11 \mathrm{mg} / \mathrm{kg}$ after frying. The main cholesterol oxides were 7 -ketocholesterol and $7 \beta$-hydroxycholesterol.

Kowale et al. (1996) found mutton to contain approximately $1 \mathrm{~g}$ cholesterol $/ \mathrm{kg}$ meat. The most abundant cholesterol oxides were $\alpha$ and $\beta$ epoxides of cholesterol and 7-ketocholesterol, results similar to those for beef (Nam et al., 2001). Novelli 
et al. (1998) studied the concentration of cholesterol oxides in fresh pork, in pork stored frozen for 1, 3 and 6 months, and in cured meats produced from this pork (salami and mortadella). In the samples prepared at a laboratory and in those purchased in shops, the concentration of cholesterol oxides varied greatly, which was probably caused by different quality of meat samples and storage conditions.

\section{Level of oxysterols in eggs and egg products}

The egg yolk contains the highest level of cholesterol of all animal products. The amount of cholesterol in one egg yolk averages $213 \mathrm{mg}$ (Anon, 1990). The contents of egg yolk is conducive to the processes of lipid oxidation and formation of the COPs due to a high quantity of cholesterol and iron as well as the presence of polyunsaturated fatty acids. Thus it is believed that powdered egg products contain the highest amount of COPs compared with other foods.

Polyunsaturated fatty acids are especially susceptible to oxidation processes during which free radicals and peroxides are formed, which in turn contribute to the cholesterol oxidation and creation of COPs (Ubhayasekera et al., 2005). Exposure to light, the content of water, storage and transport conditions as well as technological processes used during the production of the egg powder and food containing egg powder additionally affect the formation of COPs (Mazalli and Bragagnolo, 2007).

A lot of research has been carried out in order to define COPs levels in eggs and egg products because they are a common ingredient in many diets and processed foods. The most abundant COPs in eggs and egg products are $7 \alpha$-hydroxycholesterol, 7ß-hydroxycholesterol and its dehydrogenation: $7 \alpha$-ketocholesterol, 5,6 $\alpha$-epoxycholesterol, and 5,6ß-epoxycholesterol and the products of their dehydrogenation: cholestantriol as well as 20ß-hydroxycholesterol and 25-hydroxycholesterol (Paniangvait et al., 1995; Obara et al. 2006; Hur et al., 2007; Mazzali and Bragagnolo, 2007).

Sarantinos et al. (1993) and Tsai and Hudson (1984) reported that no cholesterol oxides were found in fresh hen's egg yolk and eggs stored in a refrigerator. Also Mazzali and Bragagnolo (2009), just like Paniangvait et al. (1995) found only small amounts of COPs in fresh raw eggs enriched with $n-3$ fatty acids. In their further research they determined how the amount of COPs in eggs is dependent on the storage conditions and culinary processes. The eggs enriched with $n-3$ fatty acids and stored at $5^{\circ} \mathrm{C}$ or $25^{\circ} \mathrm{C}$ after 45 days were characterized by a decreased level of polyunsaturated fatty acids. At the same time the amount of 7-ketocholesterol, $7 \alpha$-hydroxycholesterol and $7 ß$-hydroxycholesterol increased significantly. The level of oxysterols in the yolk of raw eggs at 0 and 45 days was 0 and $11 \mu \mathrm{g} / \mathrm{g}$ respectively, but the boiled eggs contained 0.16 and $14 \mu \mathrm{g} / \mathrm{g}$. The highest levels of oxysterols $(0.44$ and $34 \mu \mathrm{g} / \mathrm{g})$ were found in fried eggs. The yolks of eggs stored at $5^{\circ} \mathrm{C}$ were characterized by a lower content of oxysterols.

Storage temperature did not affect the concentrations of $7 \alpha$-hydroxycholesterol and 7ß-hydroxycholesterol and only the level of 7-ketocholesterol was dependent on the storage temperature (Mazzali and Bragagnolo, 2009). In an earlier study Sarantinos et al. (1993) reported that frying and boiling had accelerated the formation of 
$7 \alpha$-hydroxycholesterol and 7ß-hydroxycholesterol and their level had increased from 38 to $67 \mu \mathrm{g} / \mathrm{g}$. The authors did not find any presence of 7-ketocholesterol in fried and boiled fresh eggs.

The main factor affecting the formation of oxysterols in powdered eggs is the drying of eggs. The level of oxysterols also depends on the chemical composition of egg yolk and storage conditions of the final product (Mazzali and Bragagnolo, 2007; Verado et al., 2010). The level of oxysterols in the powdered egg ranges from 8 up to $313 \mathrm{mg} / \mathrm{kg}$ (Lercker and Rodriquez-Estrada, 2000). In the 6th and 12th month of dark storage of the powdered egg at $25^{\circ} \mathrm{C}$, the level of oxysterols amounted to $77 \mu \mathrm{g} / \mathrm{g}$ and $102 \mu \mathrm{g} / \mathrm{g}$, respectively. Mazzali and Baragognolo (2007) demonstrated that 5,6 $\alpha$-epoxycholesterol and 5,6ß-epoxycholesterol were the dominating oxysterols to occur during the storage of powdered egg. The concentration of products of COPs in the powdered egg grows along with the extension of the storage time ( $\mathrm{Li}$ et al., 1996; Mazzali and Bragagnolo, 2007). The exposure to oxygen and light are also factors inducing the formation of COPs (Guardiola et al., 1997). Mazzali and Bragagnolo (2007) indicate that COPs have increased during storage, which can be attributed to the storage temperature and the low water activity, which favour lipid oxidation. Water contents in powders had a highly significant influence on oxysterols accumulation during the storage time (Obara et al., 2006). In their studies Obara et al. (2006) describe the contents of the COPs in spray-dried egg powder and freeze-dried egg powder. The cholesterol oxidation product occurred in higher quantities in spray-dried egg powders than in freeze-dried egg powders after 3 months of storage. Oxysterols present in the highest amounts in stored egg powders were 5,6-epoxycholesterol isomers. These results were consistent with earlier studies by Li et al. (1996).

The content of oxysterols in processed eggs was significantly affected by laying hen diets. Li et al. (1996) found that adding vitamin $E$ to the diet of laying hens reduced oxysterol formation during the process of spray-drying eggs, as well as prevented the formation of COPs during the storage of the egg powder.

Galobart et al. (2002) studied the effect of fatty acid-enriched diet and $\alpha$-tocopheryl acetate added to the diet of laying hens on the formation of oxidized forms of cholesterol during the egg powder storage. There was a significant correlation between the content of oxysterols depending on the type of added fat and the level of dietary vitamin E. Eggs from hens fed the sunflower oil with the addition of $\alpha$ tocopheryl acetate and from hens fed without the $\alpha$-tocopheryl acetate supplement were subjected to spray-drying processes, and the resulting egg powder was stored in the dark at room temperature. COPs concentration in egg powder after 12 months of storage was 18.1 and $39.3 \mu \mathrm{g} / \mathrm{g}$. Egg powder produced from eggs from hens fed with sunflower oil and the $\alpha$-tocopheryl acetate supplement was characterized by a lower degree of lipid oxidation and a lower content of oxysterols. The dietary inclusion of vitamin $\mathrm{E}$ in laying hen diets reduced COPs formation during the storage of the egg powder (Li et al., 1996; Galobart et al., 2002).

Verado et al. (2010) analysed the content of COPs in three different egg products. Pasteurized eggs obtained from organically farmed hens were characterized by the lowest level of COPs $(18.2 \mu \mathrm{g} / \mathrm{g})$. The authors suggest that the low levels 
of oxysterols were probably caused by a high content of natural antioxidants in the diet of laying hens. Also Li et al. (1996) and Galobart et al. (2002) indicate that vitamin E prevents formation of oxysterols during the egg drying process. Pasteurized eggs from conventional breeding contained COPs at the level of $29.2 \mu \mathrm{g} / \mathrm{g}$. Pasteurized spray-dried eggs obtained from conventional breeding were characterized by the highest level of COPs $(76.4 \mu \mathrm{g} / \mathrm{g})$. High levels of COPs in the final egg powder product resulted from using an industrial process of drying eggs, which is one of the main factors influencing the formation of oxysterols (Guardiola et al., 1997). As reported by other authors 7-ketocholesterol, $7 \alpha$-hydroxycholesterol, oraz 7ß-hydroxycholesterol were the dominant products of cholesterol oxidation (Hur et al., 2007; Mazzali and Bragagnolo, 2007). The resulting products were used for making pasta. The level of COPs in the pasta stored for 12 months with light exposure amounted to $163.1,164.7$ and $152.3 \mu \mathrm{g} / \mathrm{g}$ of fat respectively. Pasta kept in the dark contained significantly lower concentrations of COPs: $42.3,69.8$ and $60.2 \mu \mathrm{g} / \mathrm{g}$ (Verado et al., 2010). Thus, an important factor inhibiting the creation of COPs in products is also limited exposure to light (for example, through the use of opaque packaging). Another factor helping to improve the quality and health value of the product obtained is feeding the hens a diet containing vitamin $\mathrm{E}$ and choosing the industrial process which generates the lowest amounts of COPs.

\section{Level of oxysterols in milk products}

Fresh chilled milk and dairy products contain no COPs (Sieber, 2005) or they are present in trace amounts (Sander et al., 1989). The process of pasteurization and UHT (ultra-high temperature processing) does not significantly affect growth levels of COPs in the milk (Sieber, 2005). Also, dairy products immediately after preparation did not contain detectable amounts of COPs in low and medium temperatures, and the method of roller and spray drying was used for their production (Chan et al., 1993). Exposure of dairy products to fluorescent light contributes to the increase in oxysterol content. It is believed that dairy products are more resistant to autoxidation of cholesterol, even during a prolonged period of storage under unfavourable conditions. This is due to low-valence transition metals ( $\mathrm{Fe}, \mathrm{Cu}, \mathrm{Co})$, a mild cholesterol and saturated fats environment (Addis and Park, 1992). The most common COPs in the dairy products are $7 \alpha$ - and $7 \beta$-hydroxysterol, $\alpha$ - and $\beta$-epoxycholesterol, 7-ketocholesterol, 20 $\alpha$ - and 25-hydroxycholesterol (Przygoński et al., 2000). To date, these oxysterols were found, among others, in the following dairy products: milk powder, cheese, butter and cream.

Drying technology has a major impact on the level of cholesterol oxides in powdered milk, both immediately after drying and during storage (Appelqvist, 1996). There were no oxysterols in fresh powder milk, whole milk powder or skim milk powder, produced using full roller dried and spray method (Nourooz-Zadeh and Appelqvist, 1988; Rose-Sallin et al., 1997). Milk powder made from whole milk or skimmed at high temperatures, contained COPs at 2.8 and $7.6 \mathrm{mg} / \mathrm{kg}$ in the fat, respectively (Rose-Sallin et al., 1997).

Nourooz-Zadeh and Appelqvist (1988) and Angulo et al. (1997) received a similar amount of COPs in whole and skimmed milk powder. According to Przygoński 
et al. (2000), COPs content in milk powder was $5.85 \mathrm{mg} / \mathrm{kg}$ in the lipid extract. Mc Cluskey et al. (1997) and Mc Cluskey (1997) found significantly higher levels of COPs in the milk powder dried at high temperatures compared to the powder obtained using low temperatures. According to these authors, milk powder produced using low temperature contained COPs at $0.66 \mu \mathrm{g} / \mathrm{g}$ in the lipid extract, while the concentration of COPs in the milk powders obtained using high temperature was $1.6 \mu \mathrm{g} / \mathrm{g}$ in the lipid extract. It was found that milk powder produced from milk of cows fed a diet rich in antioxidants, using both low and high temperatures, was characterized by lower content of COPs $(0.43$ and $1.07 \mu \mathrm{g} / \mathrm{g}$, respectively) in the lipid extract (Mc Clusky et al., 1997). In addition, whole milk powder, derived from cows supplemented with vitamin E, was characterized by a higher content of antioxidants and higher oxidative stability of lipids and cholesterol, during storage at elevated temperature (Mc Clusky et al., 1997). Also Mc Clusky (1997) conducted a study to determine the content of COPs in Irish commercial milk powder, and detected no COPs in whole and skimmed fresh milk powder, obtained in the process using low temperature while the concentration of COPs in the spray-dried powders using high temperatures has increased significantly. 7-ketocholesterol and $5 \alpha, 6 \alpha$,-epoxycholesterol were present only in whole powdered milk in amounts of 1.25 and $1.23 \mu \mathrm{g} / \mathrm{g}$ in fat. The level of 5 $\beta, 6 \beta$-epoxycholesterol powder and skim milk was $1.78 \mu \mathrm{g} / \mathrm{g}$ of fat (Mc Clusky et al., 1997). Milk powder produced in the presence of inert gases or obtained using a low temperature drying, and then stored in tight containers, contained only trace amounts of COPs (Savage, 2002).

Like fresh butter, fresh cream does not contain detectable amounts of COPs (Pie et al., 1990). In another study, Kumar and Singhal (1992 b) found the limit of detection $(0.1 \mathrm{mg} / \mathrm{kg}$ fat $)$ for $7 ß$-hydroxycholesterol, $5 \beta, 6 \beta$-epoxycholesterol and 7-ketocholesterol. Pie et al. (1990) also noted the presence of a small amount of 7-ketocholesterol. Total content of COPs in the butter and dairy products was 1.4 and $2.7 \mathrm{mg} / \mathrm{kg}$ of fat. Fresh butter heated for 10 minutes at $170^{\circ} \mathrm{C}$ and for 10 and 20 minutes at $180^{\circ} \mathrm{C}$, resulted in an increased amount of COPs to the level of 13.9, 14.6 and $27.3 \mathrm{mg} / \mathrm{kg}$. Heating the butter after 2 months of storage to a temperature of $170-175^{\circ} \mathrm{C}$ for 5 and $15 \mathrm{~min}$., had no significant effects on the content of oxysterols (Rose-Sallin et al., 1997). Storing butter at $-20^{\circ} \mathrm{C}$ for 3 months resulted in the emergence of ketocholesterol $(0.97 \mathrm{mg} / \mathrm{kg})$. Butter stored in the same conditions, but for 6 months contained $0.44 \mathrm{mg} / \mathrm{kg}$ of ketocholesterol, $0.22 \mathrm{mg} / \mathrm{kg}$ of hydroxycholesterol, and $1.52 \mathrm{mg} / \mathrm{kg}$ of the $\alpha$ and B-epoxycholesterols (Pie et al., 1990). Nielsen et al. (1996) found no formation of COPs in the butter stored for 13 weeks at $-18^{\circ} \mathrm{C}$ and $4^{\circ} \mathrm{C}$. Low temperature storage of butter without exposure to light lowers the rate of oxidation of cholesterol. Heisberger and Luf (2000) studied the generation of cholesterol oxides in butter stored at around $20^{\circ} \mathrm{C}$ and at $4{ }^{\circ} \mathrm{C}$ in the presence of normal light and ultraviolet light. Butter was frozen and then kept in cold storage for 6 months. The butter was found to contain only trace amounts of COPs. In the next stage of the study the authors found that in samples stored for 3 weeks in the refrigerator with light the quantity of COPs increased significantly, while the storage of butter at room temperature after a few days resulted in the emergence of very large amounts of COPs. 
Ghee is a product of Indian butter clarified mostly at $105-118^{\circ} \mathrm{C}$ (Sserunjogi et al., 1998). Ghee is mainly produced from cow's milk or buffalo milk or a mixture of both (Rajorhia, 1993). It is used as an additive in bread, lentils or cooked rice, as a flavouring, and as a medium for cooking and frying (Kumar et al., 2010). A significant amount of ghee is also used by confectioners and bakers. Approximately $15-20 \%$ of ghee produced is used for frying and cooking (Sserunjogi et al., 1998). Cholesterol in ghee is in the range of $0.3-0.4 \%$ (Nath et al., 1996). Research by Nath et al. (1996) showed that the ghee produced and stored under normal conditions does not contain COPs and can be consumed even after 6-8 months of storage at ambient temperature. The stability of ghee during storage is attributed to low humidity and high content of phospholipids (Achaya, 1997). It is suggested that the low acidity of ghee and the presence of natural antioxidants also help to extend its life (Van den Berg, 1988). Ghee made from cow's milk is more stable during storage compared to ghee made from buffalo milk due to its higher content of natural antioxidants (Van den Berg, 1988). Sripad et al. (1996) suggested that the antioxidant properties of the residue ghee are due to the presence of tocopherols, phospholipids, and the browning reaction products. The authors found that the fat-insoluble compounds present in the residue, have better antioxidant properties than lipid-insoluble compounds. Addition of ghee residue to ghee prolongs shelf life. The addition of the alcohol extract containing the compounds of the Maillard reaction significantly delayed the processes of oxidation of lipids and cholesterol (Bector et al. 1996; Sripad et al., 1996). Use of ghee for frying for a short period did not result in the formation of cholesterol oxides, but the same culinary process lasting 15 min generated COPs. Cholesterol oxidation products were present in the frying ghee for 60 minutes (Nath et al., 1996). Kumar and Singhal (1992 b) studied the influence of the conditions of production on the level of COPs in ghee. They found that ghee contains a high amount of saturated fatty acids and cholesterol oxidation products, which mainly arise in the process of prolonged heating of ghee at about $120^{\circ} \mathrm{C}$ for $20-30 \mathrm{~min}$. The total content of COPs in the ghee produced from cow's milk was $15.0 \mathrm{mg} / \mathrm{kg}$ (Kumar and Singhal, $1992 \mathrm{~b}$ ) and $21.4 \mathrm{mg} / \mathrm{kg}$ (Kumar et al., 1999). In the ghee produced from buffalo milk the level of COPs was $20.9 \mathrm{mg} / \mathrm{kg}$ (Kumar and Singhal, $1992 \mathrm{~b}$ ). Total COPs content of $285 \mathrm{mg} / \mathrm{kg}$ was found in ghee heated at $120^{\circ} \mathrm{C}$ for $45-50 \mathrm{~h}$ (Kumar et al., 1999). Exposure of ghee to the heating process causes an increase in oxysterol.

Soft and hard cheese contain trace amounts of COPs $(0.5-2.2 \mathrm{mg} / \mathrm{kg}$ of lipid fraction), except for the fat grated cheese such as Parmesan and Romano, which contain higher amounts of oxysterols (6 and $32 \mathrm{mg} / \mathrm{kg}$ in the lipid fraction). Parmesan cheese stored for a year, with light exposure and at a temperature of $37^{\circ} \mathrm{C}$ contained significant quantities of 7-ketocholesterol $(10.1 \mathrm{mg} / \mathrm{kg}$ fat $-3.3 \mu \mathrm{g} / \mathrm{g}$ cheese) (Kristensen et al., 2001). However, Parmesan, stored for 25 months at $-24^{\circ} \mathrm{C}$ in the original packaging intact, contained trace amounts of 7-ketocholesterol (Rose-Sallin et al., 1997). Nielsen et al. (1996) considered as an indicator ketocholesterol oxidation of cholesterol in the cheese and other dairy products. Cheese stored for 6 months protected from light at $21-38^{\circ} \mathrm{C}$ was characterized by small changes in the amount of COPs (Rose-Sallin et al., 1997; Kristensen et al., 2001). Cheese from damaged packages, and transparent packaging, in which each slice is packed separately, was 
characterized by the highest content of COPs $(70-80 \mathrm{mg} / \mathrm{kg}$ ) (Rose-Sallin et al., 1997). In the sliced cheese and yellow grated cheese, at 55 and 20 days of exposure to fluorescent light, there were no significant changes in the concentration of COPs (Nielsen et al., 1996).

Suitable processing conditions (using low or medium temperatures in the dairy industry) and food storage (sealed, opaque container, proper storage temperature) minimize oxidation of cholesterol levels. Formation of COPs can be reduced by feeding animals with a diet rich in natural antioxidants.

\section{Effect of fatty acids oxidation on meat quality}

Autoxidation of lipids occurring in meat and meat products is an extremely complex process and is one of the major causes of deterioration in the quality of these products. They are responsible for degradation of colour, flavour and texture, as well as loss of their nutritive value (Gray et al., 1996; Hęś et al., 2007). This is due, among others, to high susceptibility of primary, intermediate and final products of oxidation to the distribution and reaction with other constituents of meat, the complex influence of catalysts and the impact of natural antioxidants and photo-oxidation occurring simultaneously with the autoxidation. The most widely used test of lipid oxidation of meat is TBARS assay (Juntahote et al., 2007). One of the main secondary products appearing in reaction with thiobarbituric acid (TBA) is malondialdehyde (MDA), commonly present in decomposing fat. It belongs to the most typical products of lipid oxidation of meat, and its determination is considered to be one of the most sensitive and specific methods used to assess the rate and extent of lipid oxidation in meat.

The most important volatile components formed during lipid oxidation which influence meat aroma are chemical compounds built of heterocyclic rings containing sulfur and/or nitrogen, which include lactones, alkylfurans, alkylpyridines and alkylthiazoles (Mottram, 1998). They are present in very low concentrations and have a very low threshold of flavour. The main input of fatty acids in the synthesis of these volatile components is to provide the aldehydes, from which rings of the compounds mentioned above are synthesized. Main aldehydes giving unwanted smell are hexanal, pentanal and propanal. Furthermore, due to the degradation of amino acids the amino groups are detached and amines are formed and in the case of cysteine sulfine appears. Monosaccharides, mainly ribose, react with amino groups to give Maillard compounds of which the most important are $\alpha$-dicarbonyl and $\alpha$ hydroxyketone. Many of these lipid oxidation products are formed in the culinary process, especially during cooking, frying or grilling which is facilitated by high temperature. Pork from pigs which received grain in feed mixture is characterized by a high content of linoleic acid (C18: 2$)$ belonging to the family of $n-6$ fatty acids. The consequence of this was an unexpected increase in the ratio of $n-6$ to $n-3$ fatty acids, which is undesirable from the point of view of consumer health. What is more, in meat containing higher levels of linoleic acid (C18:2), which during boiling is rapidly oxidized, off-flavour products are formed, mainly pentanal and hexanal, which are responsible for characteristic rancid smell of pork (Enser, 1999). The other products of oxidation of linoleic acid (C18: 2) created during pork cooking are 2.4-decadienal 
and 2-pentylfuran. Another important fatty acid of n-6 family, commonly present in pork is arachidonic acid (C20: 4). Its main product of oxidation, 1-octen-3-ol gives the meat a distinctive mushroom smell (Mottram, 1998).

In contrast, $\alpha$-linolenic acid (C18:3), the main sources of which are fish oils, flaxseed and canola, is a precursor of $n-3$ fatty acids. As a result of oxidation of these acids, meat smell becomes unacceptable to the consumers because of its fish odour. Carriers of this undesirable odour are $\alpha$-linolenic acid (C18:3), eicosapentaenoic acid (C20:5) and docosahexaenoic acid (C22:6). Studies by American and British scientists found that a $3 \%$ content of these acids in the whole meat lipids is the upper limit accepted by consumers. The comparative work's aim was to assess which meat is more preferred by consumers - that richer in $n-3$ or $n-6$ acids. The research showed that meat containing more fatty acids of $n-6$ family (derived from linoleic acid, C18:2) had a more pleasant flavour.

Hardness, firmness and juiciness of meat are closely related to the content of water in muscle tissue, collagen and the level of stearic acid $(\mathrm{C} 18: 0)$ and linoleic acid (C 18:2). Fatty acids stearic and linoleic differ in melting point $\left(69.6\right.$ and $-5^{\circ} \mathrm{C}$, respectively), which significantly affects the density and firmness of the meat. It was also found that stearic acid (C18:0) plays a greater role in creating these characteristics. Extensive research on the effects of fatty acid composition on the taste of meat, showed a positive correlation between this trait and saturated and monounsaturated fatty acids and a negative correlation for unsaturated fatty acids (Wood et al., 2004).

\section{Effect of oxysterols on cell membranes}

The interactions of cholesterol and phospholipids are essential to the normal structure and function of cell membranes. The exposure of cell culture to COPs contributes to a change in the molar ratio of sterols to phospholipids. This occurs after the introduction of COPs to cell membranes or through inhibition of cholesterol biosynthesis and thus by way of a reduction in cholesterol availability during the membrane formation process. These phenomena may reduce membrane fluidity and stability (Smith, 1996).

Proteins that serve important functions in cell membranes, such as energy carriers, receptors, enzymes, and molecular pumps and gates, are surrounded by a double lipid layer. COPs can affect the position of proteins in the structure of cell membranes and thus change their properties (Ikonen, 2008). Because of their effect on the cell metabolism and transport of fatty acids, they can alter the composition and transport of triglycerides to smooth blood vessel cells and completely change phospholipid structure, thereby contributing to cell membrane damage (Igene and Pearsons, 1979; Poli et al., 2009).

\section{Cytotoxicity of oxysterols}

American studies have confirmed that a high cholesterol content in food increases the incidence of cancer and coronary heart disease (Ansari et al., 1978; Grundy, 1990).

Despite the extensive knowledge of the composition of atheromatous plaque and the different mechanisms by which it has developed, it has still not been established 
which etiological factor or pathogenic mechanism makes the greatest contribution to the generation of atherosclerotic lesions. The most widespread view is that the formation of atherosclerotic lesions is the reaction of the vascular wall to mechanical, chemical, toxic, viral or immunological factors that trigger endothelial vessel damage. Many studies have shown that 25-hydroxycholesterol and cholestanetriol are toxic factors associated with arteriosclerosis (Taylor et al., 1979). One of the toxic products of cholesterol oxidation - 25-hydroxycholesterol - is absorbed in mammals after inclusion in the diet and causes damage to the surface of blood vessels (Poli et al., 2009), as shown by electron microscope scanning (Peng et al., 1982). Vessel infiltration by macrophages and lipoproteins and proliferation of smooth muscle and connective tissue cells are the response to the repair capacity being exceeded following repeated damage, and to the interaction of the plaques with the vascular wall. Epidemiological and experimental studies and clinical observations have documented that hypercholesterolemia, particularly an increase in LDL cholesterol, significantly increases the possibility of atherosclerotic damage, by initiating atherosclerotic damage, by increasing lipid infiltration, or by the involvement of both hypercholesterolemia and LDL cholesterol in atherosclerotic damage. One hypothesis states that oxysterols are responsible for arterial wall damage, and thus for the initiation of atherosclerotic changes. The significance of COPs for the development of atherosclerosis is evidenced by their presence in human blood, aortal tissues and atheromatous plaques (Hubbard et al., 1989; Poli et al., 2009).

It is likely that oxidized lipoproteins and associated oxysterols play an additional role in neurological disorders in the central nervous system, especially those associated with oxidative stress. Oxidative stress has been implicated in central neuronal loss in many age-related neurodegenerative diseases such as Parkinson's disease and Alzheimer's disease (Halliwell, 1992; Poli et al., 2009; Otaegui-Arrazola et al., 2010). Given the observations that oxysterols are directly neurotoxic and also regulate neuronal survival through glial cells, there is a need for detailed studies on the effects of oxysterols on neuronal-glial interactions, especially as they relate to neuroimmune functions. COPs also affect the metabolism of arachidonic acid and its oxidized metabolites, eicosanoids, which, without activation of cyclooxygenases and calcium channels, contribute to the development of inflammatory changes.

Recently it has been assumed that phytosterols (plant sterols present in oil, often used for frying) can be preventive in an impending atherosclerosis and hypercholesterolemia mainly by lowering the cholesterol level in blood (Hicks and Moreau, 2001). The phytosterols have similar oxysterol instability as cholesterol, and formation of oxysterols may negatively affect health due to the already proven negative effect of oxyphytosterols on some metabolic processes (Oehrl and Boyd, 2004; Rudzińska et al., 2009). Also phytosterol oxidation products can have similar cytotoxic and apoptic effect on human cells as cholesterol oxidation products (Ryan et al., 2005). It was shown that significantly higher amounts of phytosterol oxidation products must be used to achieve the same level of toxicity caused by COPs (Ryan et al., 2005). 


\section{Cholesterol oxidation and neoplasms}

Studies on the role of COPs in neoplastic diseases are still at the stage of intensive clinical tests. Findings to date have indicated their potentially major role in inducing some types of neoplasms (Smith and Johnson, 1989). The earliest finding was that many oxidation products induced sarcomas and other tumours when they were injected subcutaneously into animals. A role in skin cancer was said to be played by $\alpha$-epoxy-C. Etiologically, colon cancer is also associated with COPs. A higher than normal level of triol-C has been found in patients with colon cancer and in patients with precancerous lesions such as adenomatous polyps or ulcerative colitis. A higher than normal level of $\alpha$-epoxy-C has been detected in samples taken from the breasts of women with benign neoplasm. Likewise, higher levels of $\alpha$-epoxy-C and $\beta$-epoxy$\mathrm{C}$ have been observed in prostate fluids in men with an enlarged prostate, which may be related to the further development of prostate cancer. It was found that $\alpha$-epoxy$\mathrm{C}$ is mutagenic in fibroblast cultures and evokes morphological transformations in embryonic cells of the hamster and mouse.

\section{Conclusions}

There has been growing interest in studies aimed at obtaining high quality animal products that satisfy the nutritive requirements of humans while meeting all the food safety requirements.

It is still impossible to accurately define the dietary level of COPs that may be detrimental to human health. Therefore, it seems appropriate to reduce COP levels in animal products, including meat and meat products, by preventing the autoxidation of lipids. Storage of meat and meat products in packages made from appropriate materials and at low temperatures, and the use of antioxidants, may help reduce the level of toxic COPs and improve the sensory quality of these products.

Analysis of all cholesterol-containing foods should be continued. The highest priority should be given to studies on the toxicity of COPs in food, because current findings clearly show that many cholesterol oxides are cytotoxic, atherogenic, mutagenic and carcinogenic. Although some published COPs levels seem reliable, there is an urgent need to repeat the determination of many products using the increasingly precise and reliable analytical methods. Because the complete elimination of COPs from the human diet may be impossible, studies on their toxic effect on the human body should continue.

\section{References}

A c h a y a K.T. (1997). Ghee, vanaspati and special fats in India. In: Lipid Technologies and Applications, Gunstone F.D., Padley F. (eds.). Marcel Dekker Inc., New York, pp. 369-390.

A d d i s P.B., P a r k S.W. (1992). Cholesterol oxides content of foods. In: Biological Effect of Cholesterol Oxides, Peng S.K., Morin J.M. (eds.). CRC Press: Boca Raton, pp. 71-88.

A h n D.U., N a m K.C., D u M., J o C. (2001). Effect of irradiation and packing conditions after cooking on the formation of cholesterol and lipid oxidation products in meat during storage. Meat Sci., 57: 413-418.

Ang u 1 o A.J., R o m e r a J.M., R a m ire z M., G i 1 A. (1997). Determination of cholesterol oxides in dairy products. Effect of storage condition. J. Agric. Food Sci., 45: 4318-4323. 
A n o n (1990). Today's eggs contain 25\% less cholesterol. Nutrition Close-Up, 6, p. 1.

A n s a ri G.A.S., S m a r t V.B., S m ith. L.L. (1978). Mutagenicity of autoxidized cholesterol samples. Pharmacology, 20, p. 155.

A p p e lqvis t L.A. (1996). Oxidized sterols. Bull. Int. Dietary Fed., 315: 52-58.

B a u m an D.R., B itman s our A.D., M c Donald J.G., Thompson B.M., Li ang G., Rus s e 11 D.W. (2009). 25-hydroxycholesterol secreted by macrophages in response to toll-like receptor activation suppresses immunoglobulin A production. Proc. Natl. Acad. Sci., 106: 16764-16769.

B e ctor B.S., A bi chandani H., S a r a m a S.C. (1996). Shelf life of ghee manufactured in continuous ghee making system. Indian J. Dairy Sci., 49: 398-405.

Bos elli E., Rodriguez-Estrada M.T., Fedrizzi G., Caboni M.F. (2009). Cholesterol photosensitized oxidation of beef under standard and modified atmosphere at retail conditions. Meat Sci., 81: 224-229.

B r o n c a n o J.M., P e tró n M.J., P a r r a V., T i m ón M.L. (2009). Effect of different cooking methods on lipid oxidation and formation of free cholesterol oxidation products (COPs) in Latissimius dorsi muscle of Iberian pigs. Meat Sci., 83: 431-437.

Brown J., Jess up W. (2009). Oxysterols: sources, cellular storage and metabolism, and new insights into their roles in cholesterol homeostasis. Mol. Aspects Med., 30: 111-122.

B u s c h T.P., King A.J. (2009). Artifact generation and monitoring in analysis of cholesterol oxide products. Anal. Biochem., 388: 1-14.

Chan S.H., Gra y J.I., G o u m e a E.A., Harte B.R., K elly P.M., B u c k le y D.J. (1993). Cholesterol oxidation in whole milk powders as influenced by processing and packaging. Food Chem., 47: 321-328.

Chen Y.C., Chiu C.P., Chen B.H. (1994). Determination of cholesterol oxides in heated lard by liquid chromatography. J. Food Chem., 50: 53-58.

Chizzolini R., Novelli E., Zanardi E. (1998). Oxidation in traditional mediterranean meat products. Meat Sci., Suppl., 49: 87-99.

D e rew i a k a D., O bi e d z iń s k i M. (2009). Oxysterol content in selected meats and meat products. Acta Sci. Pol. Technol. Aliment., 8: 5-13.

Derewiaka D., Obiedziński M. (2010 a). Oxysterol content in selected meat products. Eur. J. Lipid Sci. Technol., 112: 1130-1137.

D e r e w i a k a D., O b i e d z iń s k i M. (2010 b). Influence of lard heat treatment on changes in the content of cholesterol and formation of cholesterol oxidation products. Pol. J. Nutr. Sci., 60: 19-23.

D i e t s c hy J.M., T u r le y S.D. (2004). Thematic review series: brain lipids. Cholesterol metabolism in the central nervous system during early development and in the mature animal. J. Lipid Res., 45, p. 1375.

D u t t a P. (1997). Studies on phytosterol oxides. II. Content in some vegetable oils and in French fries prepared in the oils. J. Am. Oil Chem. Soc., 74: 659-666.

Echarte M., Zulet M.A., Astias aran T. (2001). Oxidation process affecting fatty acids and cholesterol in fried roasted salmon. J. Agric. Food Chem., 49: 5562-5567.

Eder K., Müller G., Kluge H., Hirche F., B rand s ch C. (2005). Concentrations of oxysterols in meat and meat products from pigs fed diets differing in the type of fat (palm oil or soybean oil) and vitamin E concentrations. Meat Sci. 70: 15-23.

Engeseth N.J., Gray J.I., Asghar A. (1993). Improved oxidative stability of veal lipids and cholesterol through dietary vitamin E supplementation. Meat Sci., 35: 1-15.

En s e r M. (1999). Nutritional effects on meat flavour and stability. In: Poultry Meat Sciences, Richardson R.I., Mead C. (eds.). CABI, Wallingford, UK, pp. 197-215.

F la czyk E., Rudzińska M., W ąs ow icz E., K orczak J., A marowicz R. (2006). Effect of cracklings hydrolysates on oxidative stability of pork meatballs fat. Food Res. Int., 39: 924-931.

Ga lobart J., Guardiola F., B arroeta A.C., L opez-Ferrer S., B a u cells M.D. (2002). Influence of dietary supplementation with $\alpha$-tocopheryl acetate and canthaxantin on cholesterol oxidation in $\alpha-3$ and $\alpha-6$ fatty acid enriched spray-dried eggs. J. Food Sci., 67: 2066-2460.

Galvin K., Morrissey P.A., Buckley D.J. (1998). Cholesterol oxides in processed chicken muscle is influenced by dietary $\alpha$-tocopherol supplementation. Meat Sci., 48: 1-9.

Gill S., Chow R., Brown A.J. (2008). Sterol regulators of cholesterol homeostasis and beyond: The oxysterol hypothesis revisited and revised. Prog. Lipid Res., 47: 391-404. 
Gortiz C., Mauch D.H., Pfrieger F.W. (2005). Multiple mechanisms mediate cholesterol-induced synapthogenesis in a CNS neuron. Moll. Cell. Neurosci., 29: 190-201.

Gray J.T., G o m a a E.A., B u chley D.J. (1996). Oxidative quality and shelf life of meats. Meat Sci., 43: 111-123.

Griffiths W.J., Wang Y. (2011). Analysis of oxysterol metabolomes. BBA - Mol. Cell Biol. Lipids, 1811: 784-799.

Grundy S.M. (1990). Cholesterol and Atherosclerosis: Diagnosis and Treatment. J.B. Lippincott Company, Philadelphia.

Guardiola F., Codony R., Add is P.B., R a fec a s M., B o a te 11 a J. (1996). Biological effects of oxysterols: current status. Food Chem. Toxicol., 34: 193-211.

Guardiola F., Codony R., Ra fec a s M., Gra u J., B o a tella J. (1997). Oxysterol formation in spray-dried egg processed and stored under various conditions: prevention and relationship with other quality parameters. J. Agric. Food Chem., 45: 2229-2243.

Halliwe 11 B. (1992). Reactive oxygen species and the central nervous system. J. Neurochem., 59: 1609-1623.

He is berger J., L u f W. (2000). Oxidation of cholesterol in butter during storage-effect of light and temperature. Eur. Food Res. Technol., 211: 161-164.

H ęś M., K or c z a k J., G r a m z a A. (2007). Changes of lipid oxydation degrees and their influence on protein nutritive value of frozen meat products. Pol. J. Food Nutr. Sci., 57(3): 323-328.

H i c k s K.B., M o r e u R.A. (2001). Phytosterol and phytostanols: Functional food cholesterol busters. Food Technol., 55: 63-67.

H u b b a r d R.W., O no Y., S a n c he z A. (1989). Atherogenic effect of oxidized products of cholesterol. Prog. Food Nutr. Sci., 13: 17-44.

H u r S.J., P a rk G.B., J o o S.T. (2007). Formation of cholesterol oxidation products (COPs) in animal products. Food Contr., 18: 939-947.

I g e n e J.O., P e a r s on A.M. (1979). Role of phospholipids and triglycerides in warmed-over flavour development in meat model systems. J. Food Sci., 44: 1285-1290.

Iguchi Y., Yamaguchi M., Sato H., Kihira K., Nishimaki-Mogami T., Une M. (2010). Bile alcohols function as the ligands of membrane-type bile activated G-protein-coupled receptor. J. Lipid Res., 51: p. 1432.

I k o n e n E. (2008). Cellular cholesterol trafficking and compartmentalization. Mol. Cell Biol., 9: $125-138$.

J a n o s z k a B. (2010). 7-ketocholesterol and 7-hydroxycholesterol in pork meat and its gravy thermally treated without additives and in the presence of onion and garlic. Meat Sci., 86: 976-984.

Juntahote T., B ergh of er E., S i e be nhandl S., B a u er F. (2007). Effect of dried galangal powder and its ethanolic extracts on oxidative stability in cooked ground pork. Food Sci. Technol., 40: 324-330.

Karu K., Hornshaw M., Woffendin G., Bodin K., Hamberg M., Alvelius G., Sjönvall J., Wang Y., Griffits W.J. (2007). Liquid chromatography-mass spectrometry utilizing multi-stage fragmentation for the identification of oxysterols. J. Lipid Res., 48: 976-987.

Kow a le B.N., R a o K., B a bu P., Sharma N., B is h t G.S. (1996). Lipid oxidation and cholesterol oxidation in mutton during cooking and storage. Meat Sci., 43: 195-202.

Kozłowska-Wojciechowska M., Jastrzębska M., Naruszewicz M., Foltyńs k a M. (2003). Impact of margarine enriched with plant sterols on blood lipids, platelet function, and fibrinogen level in young men. Metabolism, 52: 1373-1378.

Kristensen D., Hansen E., Arndal A., Trinderub R.A., Skibsted L.H. (2001). Influence of light and temperature on the colour and oxidative stability of processed cheese. Int. Dairy J., 11: 837-843.

K u m a r N., S in gh a 1 O.P. (1992 a). Cholesterol oxides and atherosclerosis: a review. J. Sci. Food Agric., 55: 497-510.

K u m a r N., S in g h a 1 O.P. (1992 b). Effect of processing conditions on the oxidation of cholesterol in ghee. J. Sci. Food Agric., 5: 267-273.

K u m a r M.V., S a m b a i a h K., L o k e s h B.R. (1999). Effect of dietary ghee - the anhydrous milk fat on blood and liver lipids in rats. J. Nutr. Biochem., 10: 96-104. 
Kumar M., Sharma V., Lal D., Kumar A., S eth R. (2010). A comparison of the physicochemical properties of low-cholesterol ghee with standard ghee from cow and buffalo creams. Int. J. Dairy Technol., 66: 252-254.

Le onarduzzi G., S ottero B., Poli G. (2002). Oxidized products of cholesterol: dietary and metabolic origin, and proatherosclerotic effect (review). J. Nutr. Biochem., 13: 700-710.

Ler c ker G., R odriguez - Es tra d a M.T. (2000). Cholesterol oxidation: presence of 7-ketocholesterol in different food products. J. Food Compos. Anal., 13: 625-631.

L e r c k e r G., R o d rig u e z - E s tra d a M.T. (2002). Cholesterol oxidation mechanisms. In: Cholesterol and phytosterol oxidation products, Guardiola F., Dutta P.C., Codony R., Savage G.P. (eds.). AOCS, Champaign, pp. 1-25.

L i S.X., C h e r i a n G., S i m J.S. (1996). Cholesterol oxidation in egg yolk powder during storage and heating as affected by dietary oils and tocopherol. J. Food Sci., 61: 721-725.

L o p e z-B o te C.J., Gra y J.I., G o m a a E.A., F l e g a l C.J. (1998). Effect of dietary administration of oil extract from rosemary and seed on lipid oxidation in broiler meat. Brit. Poultry Sci., 39: $235-240$.

Mara s chi ello C., Di a z I., García - R e gue iro J.A. (1995). Determination of cholesterol in fat and muscle of pig by HPLC and capillary gas chromatography with solvent venting injection. J. High Resol. Chrom., 19: 165-168.

Maras chi ello C., Esteve E., Garcia-Regue ir o J.A. (1998). Cholesterol oxidation in meat from chickens fed $\alpha$-tocopherol- and $\beta$-carotene-supplemented diets with different unsaturation grades. Lipids, 33: 705-713.

Mazalli M.R., B raga g n o lo N. (2007). Effect of storage on cholesterol oxide formation and fatty acid alterations in egg powder. J. Agric. Food Chem., 55: 2743-2748.

Mazalli M.R., B ra ga g n o 1 o N. (2009). Increase of cholesterol oxidation and decrease of PUFA as a result of thermal processing and storage in eggs enriched with $n-3$ fatty acids. J. Agric. Food Chem., 57: 5028-5034.

M c Clus ke y S.C.M. (1997). Cholesterol oxidation products in whole milk powder: analytical, nutritional, processing and toxicological studies. Thesis Univ. Dublin, pp. 1-297.

Mc Cluskey S., Connolly J.F., Devery R., O’Brien B., Kelly J., Harrington D., $\mathrm{S}$ t a n t o n C. (1997). Lipid and cholesterol oxidation in whole milk powder during processing and storage. J. Food Sci., 62: 331-337.

Mottram D.S. (1998). Flavour formation in meat and meat products - a review. Food Chem., 62: 415-424.

N a m K.C., D u M., J o C., A h n D.U. (2001). Cholesterol oxidation products in irradiated raw meat with different packing and storage time. Meat Sci., 58: 431-435.

$\mathrm{N}$ a th B.S., U s h a M.A., M u r th y M.K.R. (1996). Effect of deep frying on cholesterol oxidation in ghee. J. Food Sci. Technol., 33: 425-426.

Ni e l s e n J.H., O l s e n C.E., J e n s e n C., S k ri bs t e d L.H. (1996). Cholesterol oxidation in butter and dairy spread during storage. J. Dairy Res., 63: 159-167.

Nourooz-Zadeh J., Appelqvist L.A. (1988). Cholesterol oxides in Swedish foods and food ingredients: milk powder products. J. Food Sci., 53: 74-79.

Novelli E., Zanardi E., Ghiretti G.P., Campanini G., Dazzi G., Madarena G., C h i z z o li n i R. (1998). Lipid and cholesterol oxidation in frozen stored pork, salame Milano and mortadella. Meat Sci., 48: 29-40.

Obara A., Obiedzinski M., Kolczak T. (2006). The effect of water activity on cholesterol oxidation in spray-and freeze-dried egg powders. Food Chem., 95: 173-179.

O e hrl D.L., B oy d L.C. (2004). Biological effect and safety aspects of phytosterol oxides. In: Dutta P.C. (ed.). Phytosterols as functional food components and nutraceuticals. Marcel Dekker Inc., New York, pp. 419-430.

Os a d a K., Kodama T., Y amada K., Sugano M. (1993). Levels and formation of oxidized cholesterols in processed marine foods. J. Agric. Food Chem., 41: 1893-1898.

Os ada K., Hoshina S., Nakamura S., Sugano M. (2000). Cholesterol oxidation in meat products and its regulation by supplementation of sodium nitrite and apple polyphenol before processing. J. Agric. Food Chem., 48: 3823-3829. 
Otaegui-Arrazola A., Menendez-Carreńo M., Ansorena D., Astiasaran I. (2010). Oxysterols: A world to explore. Food Chem. Toxicol., 48: 3289-3303.

Paniangvait P., King A.J., Jones A.D., Germ an B.G. (1995). Cholesterol oxides in foods of animal origin. J. Food Sci., 60: 1159-1174.

P a r k S.W., A d d is P.B. (1985). Capillary column gas-liquid chromatographic resolution of oxidized cholesterol derivatives. Anal. Biochem., 149: 275-283.

Peng S.K., Taylor C.B., Mosbach E.H., Hwang W.Y., Hill J., Mikkelson B. (1982). Distribution of 25-hydroxycholesterol in phase lipoproteins and its role in atherogenesis. Atherosclerosis, 41: 395-402.

Petrón M.J., García-Regueiro J.A., Martín L., Muriel E., Antequera T. (2003). Identification and quantification of cholesterol oxidation products in different types of Iberian hams. J. Agric. Food Chem., 51: 5786-5791.

P i e J.E., S pahis K., S e illan C. (1990). Evaluation of oxidative degradation of cholesterol in food ingredients: identification and quantification of cholesterol oxides. J. Agric. Food Chem., 38: 937-979.

P i e J.E., S p a h is K., S e i 11 a n C. (1991). Cholesterol oxidation in meat products during cooking and frozen storage. J. Agric. Food Chem., 39: 250-254.

P i e s z k a M. (2007 a). Effect of vegetable oil supplementation in pig diets on lipid oxidation and formation of oxidized forms of cholesterol in meat. Polish J. Food Nutr. Sci., 57 (4): 509-516.

$\mathrm{P}$ i e s z k a M. (2007 b). Effect of supplementing pigs with vitamins $\mathrm{E}$ and $\mathrm{C}$ and $\beta$-carotene in added-fat diets on oxidative stability and oxysterols formation in meat. Ann. Anim. Sci., 7 (2): 245-258.

P i i r o n e n V., T o i v o J., L a m p i A.M. (2002). New data for cholesterol contents in meat, fish, milk, eggs and their products consumed in Finland. J. Food Compos. Anal., 15: 705-713.

Poli G., S o t t e r o B., Ga r g i u l o S., L e o n a r d u z z i G. (2009). Cholesterol oxidation products in the vascular remodeling due to atherosclerosis. Mol. Aspects Med., 30: 180-189.

Przy g oń s k i K., J e l eń H., W ą s ow i c z E. (2000). Determination of cholesterol oxidation products in milk powder and infant formulas by gas chromatography and mass spectrometry. Nahrung, 44: $122-125$.

R a j o r h i a G.S. (1993). Ghee. In: Encyclopaedia of Food Science, Food Technology and Nutrition, Macrae R., Robinson R.K., Sadler M.J. (eds.). Academic Press Ltd, London, 4, pp. 2186-2192.

R e y I., K erry J.P., L y n ch P.B., L o p e z - B o t e C.J., B u c k l e y D.J., M or r is e y P.A. (2001). Effect of dietary oils and alpha-tocopheryl acetate supplementation on lipid (TBARS) and cholesterol oxidation in cooked pork. J. Anim. Sci., 79: 1201-1208.

Rose-Sallin C., S i e ber R., B os s e t J.O., T ab a c chi R. (1997). Effects d'un stockage ou d'un traitement thermique sur la formation des oxysterols dan les produits laitiers. Lebensm. Wiss. Technol., 30: 170-177.

R o zn e r S., G a r t i N. (2006). The activity and absorption relationship of cholesterol and phytosterols. Colloid. Surface, 283: 435-456.

R u d e l L., L e e R., C o c k m a n T.L. (2001). Structure, function and regulation of ACAT. Curr. Opin. Lipidol., 12: 121-127.

Rudzińska M., Ka zuś T., Wą s ow i c z E. (2001). Sterols and their oxidized derivatives in refined and cold pressed seed oils (in Polish). Oilseed Crops, 22: 477-494.

Rudzińska M., Flaczyk E., A marowicz R., Wąs owicz E., Korczak J. (2007). Antioxidative effect of crackling hydrolysates during frozen storage of cooked pork meatballs. Eur. Food Res. Technol., 224: 293-299.

R u d zińs k a M., Pr z y b y ls ki R., W ą s ow i c z E. (2009). Products formed during thermo-oxidative degeneration of phytosterols. JAOCS, 86: 651-662.

R u s s e 11 D.W. (2000). Oxysterol biosynthetic enzymes. Biochim. Biophys. Acta, 1529: 126-135.

R y a n T.C., Gra y J.J., M ort on I.D. (1981). Oxidation of cholesterol in heated tallow. J. Sci. Food Agric., 32: 305-308.

Ryan E., Chopra J., McCarthy F.O., Maguire A.R., O'Brien N.M. (2005). Qualitative and quantitative comparison of the cytotoxic and apoptotic potential of phytosterol oxidation products with their corresponding cholesterol oxidation products. Br. J. Nutr., 94: 443-451.

Ryan E., M c Carthy F.O., Maguire A.R., Ó B ri e n N.M. (2009). Phytosterol oxidation products: their formation, occurrence and biological effects. Food Rev. Int., 25: 157-174. 
S a n d e r B.D., A d d is P.B., P a rk S.W., S m it th D.E. (1989). Quantification of cholesterol oxidation products in a variety of foods. J. Food Protect., 52: 109-114.

S a r a n t i n o s J., O ' D e a K., S in c l a ir A.J. (1993). Cholesterol oxides in Australian foods: identification and quantification. Food Aust., 45: 485-490.

S a va ge G.O., D u t t a P.C., R o dri qu e z-Estrad a M.T. (2002). Cholesterol oxides: their occurrence and methods to prevent their generation in foods. Asia Pac. J. Clin. Nutr., 11: 72-78.

$\mathrm{S}$ chroepfer G.J. (2000). Oxysterols: modulators of cholesterol metabolism and other processes. Physiol. Rev., 80: 361-554.

$\mathrm{S}$ i e b i e r R. (2005). Oxidised cholesterol in milk products. Int. Dairy J., 15: 191-206.

S i m o n s K., I k o n e n E. (2000). How cells handle cholesterol. Science, 290: 1721-1726.

S m it h L.L. (1996). Review of progress in sterol oxidations: 1987-1995. Lipids, 31: 453-487.

S m it h L.L., J o h n s o n B.H. (1989). Biological activities of oxysterols. J. Free Radicals Biol., Med., 7: 285-332.

S mith W.L., Murphy R.C. (2008). Oxidized lipids formed non-enzymatically by reactive oxygen species. J. Biol. Chem., 283: 15513-15514.

Soto-Rodriguez I., Campillo-Velazquez P.J., Ortega-Martinez J., Rodrig u e z- E s tra d a M.T., L e r c k e r G., Gr a ci a H.S. (2008). Cholesterol oxidation in traditional Mexican dried and deep-fried food products. J. Food Compos. Anal., 21: 489-495.

$\mathrm{S}$ ri p a d S., K e m p a n $\mathrm{n}$ a C., B h a t G.S. (1996). Effect of alcohol extract of defatted ghee residue on the shelf life of ghee. Indian J. Dairy Biol. Sci., 7: 82-84.

S s e ru nj o g i M.L, A brah a m se n R.K., N arvhus J. (1998). A review paper: current knowledge of ghee and related products. Int. Diary J., 8: 677-688.

T a i C.Y., Chen Y.C., Chen B.H. (1999). Analysis, formation and inhibition of cholesterol oxidation products in food: an overview (part I). J. Food Drug Anal., 7: 243-257.

T a y lor C.B., P e ng S.K., W e r th he s se n N.T., Th a m P., L e e K.T. (1979). Spontaneously occurring angiotoxic derivatives of cholesterol. Am. J. Clin. Nutr., 32: 40-57.

T s a i I.S., Hu d s on C.A. (1984). Cholesterol oxides in commercial dry egg products: isolation and identification. J. Food Sci., 49: 1245-1248.

$\mathrm{U} b \mathrm{~h}$ a y a s e $\mathrm{k}$ er a S.J.K.A., V e r 1 e y e $\mathrm{n}$ T., D u t a P.C. (2005). Evaluation of GC an GC-MS methods for the analysis of cholesterol oxidation products. Food Chem., 84: 149-157.

Valenzuela A., S anhueza J., Ni e to S. (2003). Cholesterol oxidized products in foods: potential health hazards and the role of antioxidants in prevention. Biol. Res., 36: 291-302.

V a n d e n B e r g J.C.T. (1988). Dairy technology in the tropics and subtropics. Pudoc, Wageningen, Netherlands.

Vance D., Bosch H. (2000). Cholesterol in the year 2000. Biochim. Biophys. Acta, 1529, pp. 1-8.

Verado V., Pasini F., Lafelice G., Messia M.C., Marconi E., Caboni F.M. (2010). Influence of storage conditions on cholesterol oxidation in dried egg pasta. J. Agric. Food Chem., 58: 3586-3590.

V incente S.J.V., Torres E.A.F.S. (2007). Formation of four cholesterol oxidation products and loss of free lipids, cholesterol and water in beef hamburgers as a function of thermal processing. Food Control, 18: 63-68.

Wang Y., Griffiths W.J. (2008). Steroids, sterols and the nervous system. In: Metabolomics, metabonomics and metabolite profiling, Griffiths W.J. (ed.). Royal Soc. Chem, Cambridge, pp. $71-115$.

W o od J.D., Rich ard s on R.I., N u te G.R., F i s her A.V., C a m po M.M., K a s a pid ou E., $\mathrm{S}$ h e ard P.R., En ser M. (2004). Effects of fatty acids on meat quality: a review. Meat Sci., 66 (1): 21-32.

Zaborowska Z., U chman W., Jeleń H., Rudzińska M., Wąs owicz E. (2002). Cholesterol and cholesterol oxidation products in Polish commercial sausages. E.J.P.A.U., 5 (2), http://www.ejpau.media.pl/series/volume5/issue2/food/art-01.html

Zi e mlański Ś., Budzyńska-Topolewska J. (1991). Fats of food and the systemic lipids (in Polish). Wyd. Nauk. PWN, Warszawa, pp. 1-398. 
SYLWIA ORCZEWSKA-DUDEK, DOROTA BEDERSKA-ŁOJEWSKA, MAREK PIESZKA, MARIUSZ P. PIETRAS

\section{Cholesterol i nadtlenki lipidowe w produktach zwierzęcych oraz ich wpływ na zdrowie - artykul przeglądowy}

\section{STRESZCZENIE}

Poziom oksysteroli w produktach pochodzenia zwierzęcego zależy od temperatury stosowanej w procesach przetwarzania żywności, czasu ich ogrzewania oraz od warunków i długości przechowywania. Wysoka temperatura, tlen, ekspozycja na światło, skład chemiczny produktu oraz niski poziom antyoksydantów przyspiesza powstawanie PUCh (produkty utleniania cholesterolu). Wysoka zawartość wielonienasyconych kwasów thuszczowych $\mathrm{w}$ mięsie oraz jajach generuje ich powstawanie. Produkty mleczarskie charakteryzują się najniższą zawartością PUCh spośród wszystkich produktów zwierzęcych. Najczęściej występującymi oksysterolami w produktach pochodzenia zwierzęcego są: 7-ketocholesterol, 20 $\alpha$-hydroksycholesterol, 25-hydroksycholesterol oraz $\alpha, \beta$-epoksycholesterol. Liczne badania potwierdziły niekorzystne działanie PUCh na zdrowie zwierząt i człowieka. Wykazują one działanie mutagenne, karcinogenne, angiogenne, toksyczne oraz uszkadzające błony komórkowe i hamujące biosyntezę cholesterolu. Stosowanie niektórych antyoksydantów w żywieniu zwierząt ogranicza powstawanie PUCh w czasie technologicznych procesów przetwarzania mięsa, jaj oraz mleka, jak również podczas procesu przechowywania świeżych produktów. Dodatkową ochroną przed nadmiernym procesem utleniania cholesterolu może być stosowanie odpowiednich opakowań ograniczających dostęp tlenu i światła. 